\title{
Dynamic Changes in Surface Damage Induced by High-Intensity Mining of Shallow, Thick Coal Seams in Gully Areas
}

\author{
Jianwei Li $\left(\mathbb{D},{ }^{1}\right.$ Xintian Li $\mathbb{D},{ }^{1}$ Changyou Liu $\mathbb{D}^{2},{ }^{2}$ and Xiangye $\mathrm{Wu} \mathbb{D}^{1}$ \\ ${ }^{1}$ Institute of Mining Engineering, Inner Mongolia University of Science and Technology, Baotou, Inner Mongolia 014010, China \\ ${ }^{2}$ School of Mines, China University of Mining and Technology, Xuzhou, Jiangsu 221116, China \\ Correspondence should be addressed to Jianwei Li; 18795426108@163.com and Xiangye Wu; 175874171@qq.com
}

Received 1 August 2019; Revised 29 January 2020; Accepted 7 February 2020; Published 28 March 2020

Academic Editor: Luís C. Neves

Copyright (c) 2020 Jianwei Li et al. This is an open access article distributed under the Creative Commons Attribution License, which permits unrestricted use, distribution, and reproduction in any medium, provided the original work is properly cited.

This study proposes a novel approach to study the mechanism of mining and dynamic changes in surface subsidence and geological hazard-prone regions caused by shallow, thick coal seam mining in gully areas. This approach combines field observation, threedimensional modeling, numerical simulation, and theoretical analysis based on the conditions of the Chuancao Gedan coal mine. The in situ stress field of coalbeds is influenced by the gully terrain. Shear stress becomes concentrated on the surface, causing geological disasters such as landslides and collapse of gully slopes. High-intensity mining activities increase the concentration and are more likely to cause such geological disasters. The influence area and severity vary dynamically with the expansion of the excavation area. With the continuous expansion of coal seam mining, the amplification ratio $\eta$ (the ratio of the maximum impact range of surface subsidence and the mined-out area) first increased to 3.35, then decreased, and finally reached a constant value of 2.1. The principle of road line selection is proposed based on an analysis of surface subsidence and gully slope stability on the goaf edge. The principle of subsection reinforcement of the gully slope under the dynamic influence of coal seam mining is also determined.

\section{Introduction}

As Western China has become the focus of coal mining activity, the mining scale of shallow, thick coal seams has gradually increased [1]. Intensive mining activities in these areas have increased the overburden motion range and exaggerated surface damage, such as surface collapse, landslide, and soil erosion, resulting in serious damage to the fragile ecological environment $[2,3]$. A large number of studies have been conducted to analyze the safe and sustainable mining of shallow coal seams. Qian and Huang established a mechanical structure model of the main roof in shallow coal seam mining, providing a basic method to support the design of shallow coal seam working faces [4-6]. Xu et al. classified key strata structures and analyzed surface damage caused by shallow coal seam mining [7-9]. Zhang et al. proposed a preliminary system for water conservation mining in shallow seams. This system was defined in terms of the structure, motion, and fissure distribution of the key strata and aquifuge [10-12]. Yu et al. studied the formation mechanism of mining-induced fissures in shallow coal seam mines and proposed preliminary control techniques $[13,14]$. In addition, other scholars in this field have carried out research on strata movement, mining subsidence, ecological restoration, etc. [8, 15-20]. The characteristics of mines in Western China include large coal seam thicknesses, shallow occurrences, and complicated topography. Dynamic strata pressure disasters and geological disasters are frequently observed in gully areas (see Table 1) [21-23]. To investigate this problem, Lai et al. analyzed the surrounding rock stress distribution and the strata behaviors of shallow, thick coal seam mining in gully areas [24, 25]. Wang et al. studied the overlying strata stability and the support parameter determination of shallow coal seam mining in gully areas [26-28]. Liu et al. studied mining-induced fissures in shallow, thick coal seam mining $[29,30]$. Research on the surface subsidence caused by mining activity under similar geological and geographical conditions has also attracted the attention of scholars [31-33]. Related research mainly focuses on the optimization of mining subsidence models and the field measurement of surface subsidence data $[34,35]$.

Based on the analysis of relevant literature, research on the overburden movement and on the mining-induced 
TABle 1: Statistics of accidents and the resulting damage.

\begin{tabular}{|c|c|c|c|}
\hline Mine name & Working face & Disaster type & Notes \\
\hline $\begin{array}{l}\text { Chuancao Gedan coal } \\
\text { mine }\end{array}$ & 6106 working face & $\begin{array}{l}\text { Dynamic strata pressure } \\
\text { disaster }\end{array}$ & Roof step sinking, strut burst \\
\hline Daliuta coal mine & C202 working face & $\begin{array}{c}\text { Dynamic strata pressure } \\
\text { disaster }\end{array}$ & Support crushing, water inrush \\
\hline Daliuta coal mine & 1203 working face & $\begin{array}{c}\text { Dynamic strata pressure } \\
\text { disaster }\end{array}$ & Roof step sinking, support crushing \\
\hline Huojitu coal mine & $\begin{array}{l}12304 \text { working } \\
\text { face }\end{array}$ & $\begin{array}{c}\text { Dynamic strata pressure } \\
\text { disaster }\end{array}$ & Massive roof fall, water inrush, and sand burst \\
\hline $\begin{array}{l}\text { Chuancao Gedan coal } \\
\text { mine }\end{array}$ & 6206 working face & Geological disaster & Massive landslide, surface road damage \\
\hline Bulianta coal mine & $\begin{array}{l}22307 \text { working } \\
\text { face }\end{array}$ & Geological disaster & Large-scale subsidence, water damage \\
\hline Shangwan coal mine & $\begin{array}{l}51102 \text { working } \\
\text { face }\end{array}$ & Geological disaster & Large-scale subsidence, massive landslide \\
\hline Buertai coal mine & $\begin{array}{l}42105 \text { working } \\
\text { face }\end{array}$ & Geological disaster & $\begin{array}{c}\text { Surface road damage, large-scale subsidence, and water } \\
\text { damage }\end{array}$ \\
\hline
\end{tabular}

damage is based on the two-dimensional space of the stope advancing direction. Existing studies generally use two-dimensional plane similarity simulation and numerical calculation modeling to simplify the surface gully terrain. There are also few studies on the evaluation of surface geological hazards.

The mining of shallow, thick coal seams under gully terrain in Western China is constantly expanding. The mining subsidence and surface damage in this gully area are dynamic and changing. Understanding the mechanisms involved in gully slope landslides, subsidence, and other geological disasters under the conditions in this large mining area is critical for predicting surface damage and developing methods for controlling these disasters [36-38]. Compared with other coal seam mining areas, the bedrock in the gully area is thinner and the cementation is poor. The distribution of mining stress on the overburden is affected by both the coal seam mining and the surface gully terrain. However, there are not effective methods for the quantitative expression and evaluation of the distribution and evolution of surface mining stress field and displacement field. In addition, shallow coal seam mining in gully areas is an activity in three-dimensional space involving the surface and subsurface. Therefore, combining the research methods of three-dimensional modeling and theoretical analysis is an appropriate approach. Related research has important theoretical and practical value.

In this study, field measurements, numerical simulations, and theoretical analyses were implemented to investigate the in situ stress field and displacement field caused by mining processes under the geographical conditions of gully terrains. This study serves as a reference for the evaluation of surface geological hazard-prone areas and can help guide reasonable road line selection under the dynamic influences of similar mines.

\section{Engineering Background}

The Chuancao Gedan mine is located on the Loess Plateau and is noted for its complicated topography, which includes large surface variations. The mining field is covered by unconsolidated sediments, resulting in almost complete coverage of old layers formed before the Cenozoic Erathem and the presence of bedrock only in large gullies. The Chuancao Gedan mine exploits Seam no. 6. Seam no. 6 has an average thickness of $12.8 \mathrm{~m}$, an average inclination of $5^{\circ}$, and an average burial depth of $116.6 \mathrm{~m}$. The mining sequence of Seam no. 6 is as follows: working face $6206 \longrightarrow$ working face $6205 \longrightarrow$ working face $6204 \longrightarrow$ working face $6203 \longrightarrow$ working face $6202 \longrightarrow$ working face 6201 (see Figure 1).

High-intensity mining activities lead to overburden movements and severe surface damage. During the mining period of working faces 6206 and 6205, geological disasters such as landslides and subsidence occurred in the gully area (Figures 2(a) and 2(b)), resulting in the destruction of surface buildings and roads (Figure $2(\mathrm{c})$ ). Due to serious damage to road $\mathrm{A}$ in the mining area, the line of surface roads in the mining area needs to be reconfigured and the roads need to be reconstructed. Road B has been rebuilt on a hillside approximately $200 \mathrm{~m}$ from the boundary of the mined-out area (Figure 2(d)). Consideration of the influence range of surface subsidence is important for the reinforcement of gully slopes near road B.

For the core at point $\mathrm{O}$ (Figure 2(d)), the physical and mechanical parameters of each stratum are shown in Figure 3.

\section{Three-Dimensional Modeling}

To establish a three-dimensional analysis model, Fast Lagrangian Analysis of Continua (FLAC) was used as the simulation software. In this paper, the three-dimensional version was used to simulate all processes [39, 40].

The Mohr-Coulomb model is commonly used to describe shear damage to soil and rocks. Considering that coal seam mining is a typical nonlinear deformation problem, the Mohr-Coulomb model was used in the calculation. This model uses the following yield criteria to determine the destruction of the rock mass: 


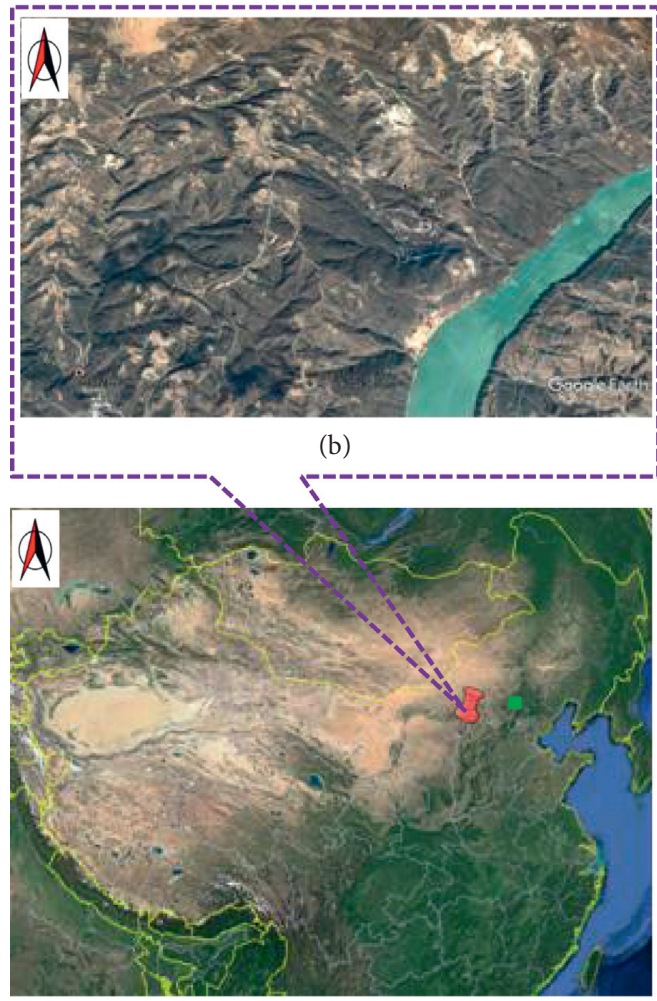

(a)

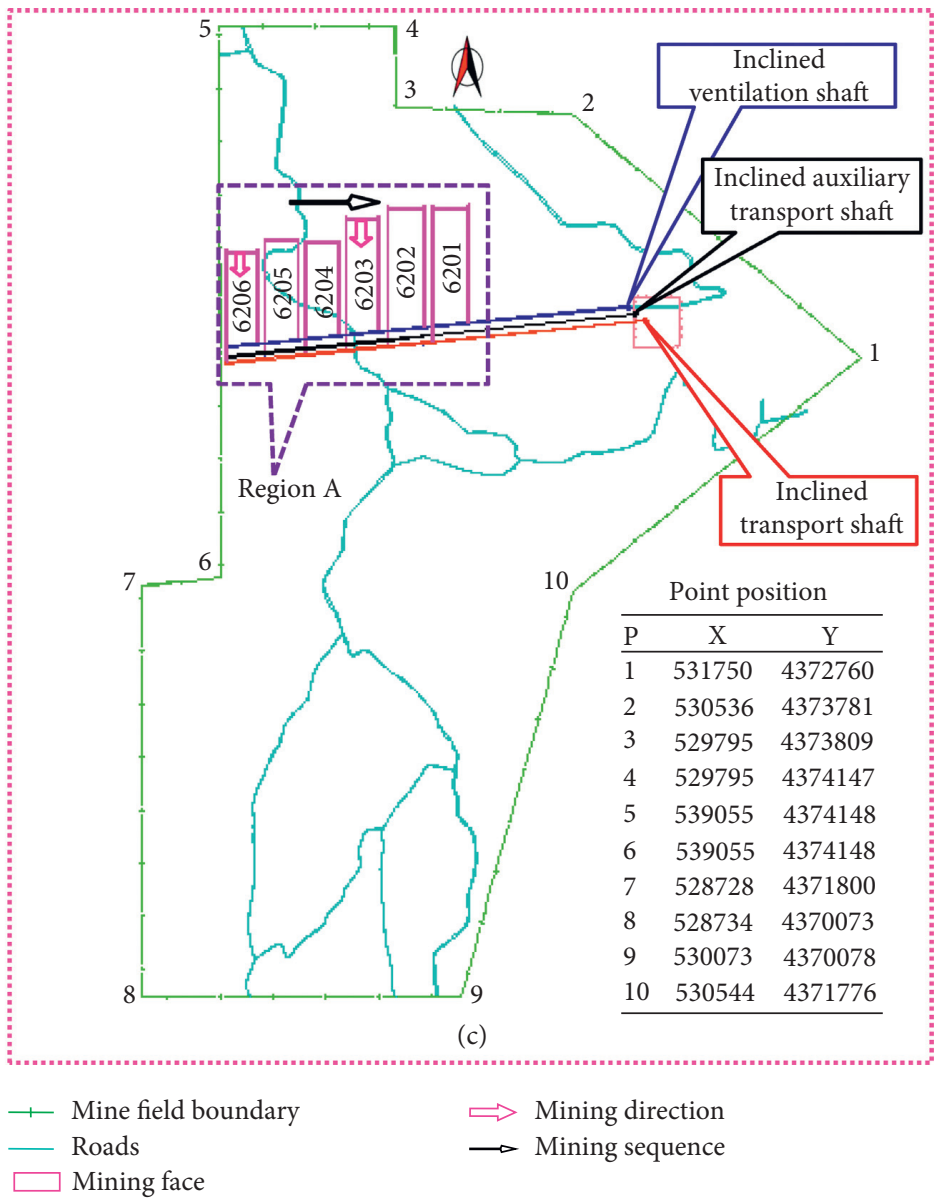

FIgURE 1: Geographical location and exploitation of Chuancao Gedan mine. (a) Mine geographical location. (b) Mine surface topography. (c) Mine exploitation area.

$$
\left\{\begin{array}{l}
f=\left(\sigma_{1}-\sigma_{3}\right)-\left(\sigma_{1}+\sigma_{3}\right) \sin \varphi-2 c \cos \varphi=0, \\
f=\left(\sigma_{3}-\sigma_{1}\right) .
\end{array}\right.
$$

In this formula, $\sigma_{1}$ and $\sigma_{3}$ are the maximum principal stress and the minimum principal stress, respectively, and $c$ and $\varphi$ are the cohesive force and internal friction angle, respectively. When $f>0$, the material undergoes shear destruction. When $f^{t} \geq 0$, the material undergoes tensile destruction.

\subsection{Establishment of an Analytical Model. Taking Region A} as an example, the three-dimensional modeling of shallow, thick coal seams in gully areas included steps such as the calculation and processing of surface contour data, the modeling of FLAC3D surface topography, the fitting of layered coal strata, and the division of mining areas. The flowchart of the model generation is shown in Figure 4.

First, three-dimensional coordinate data of the control point on the contour of the surface topography in Region A were derived. Second, the kriging interpolation method was used to organize the exported data into grid node coordinates corresponding to only one elevation form. The processed threedimensional topographic map is shown in Figure 5. The map size is $1360 \mathrm{~m} \times 1050 \mathrm{~m}(\mathrm{X} \times \mathrm{Y})$, and the map is divided into 137 rows and 106 columns with widths of $10 \mathrm{~m}$, with a total of
14,522 surface elevation data points. Third, the elevation data of each point were saved as DAT files, which contain the threedimensional coordinates of all grid nodes. The data storage form is $\left\{x_{i}, y_{j}, z_{i j}\right\}$, where $i$ is the number of rows, $j$ is the number of columns, and $z_{i j}$ is the corresponding point elevation. Finally, the FLAC3D numerical simulation software was used to generate the three-dimensional model of Region A by sequentially reading out each data point in the DAT file and creating tiny hexahedral elements. The three-dimensional model generated by the hexahedron element above an elevation of $883 \mathrm{~m}$ is shown in Figure 6.

Based on the data acquisition and processing of surface contour data, surface geomorphology modeling via FLAC3D, and formation and modeling of the underlying strata, a three-dimensional calculation model for the study area was established, as shown in Figure 7 [41]. The model size is $1360 \mathrm{~m} \times 1050 \mathrm{~m} \times 292 \mathrm{~m}(\mathrm{X} \times \mathrm{Y} \times \mathrm{Z})$; the horizontal grid size $\mathrm{X} \times \mathrm{Y}$ of the model is $10 \mathrm{~m} \times 10 \mathrm{~m}$. The vertical dimension of the model is divided into 14 layers, and the vertical grid size $Z$ is divided according to the thickness of each layer. The model has 614,040 zones and 551,836 grid points. The dimension parameters of the mining face are shown in Table 2.

According to the actual conditions, the boundary constraints adopted in this model are as follows: 


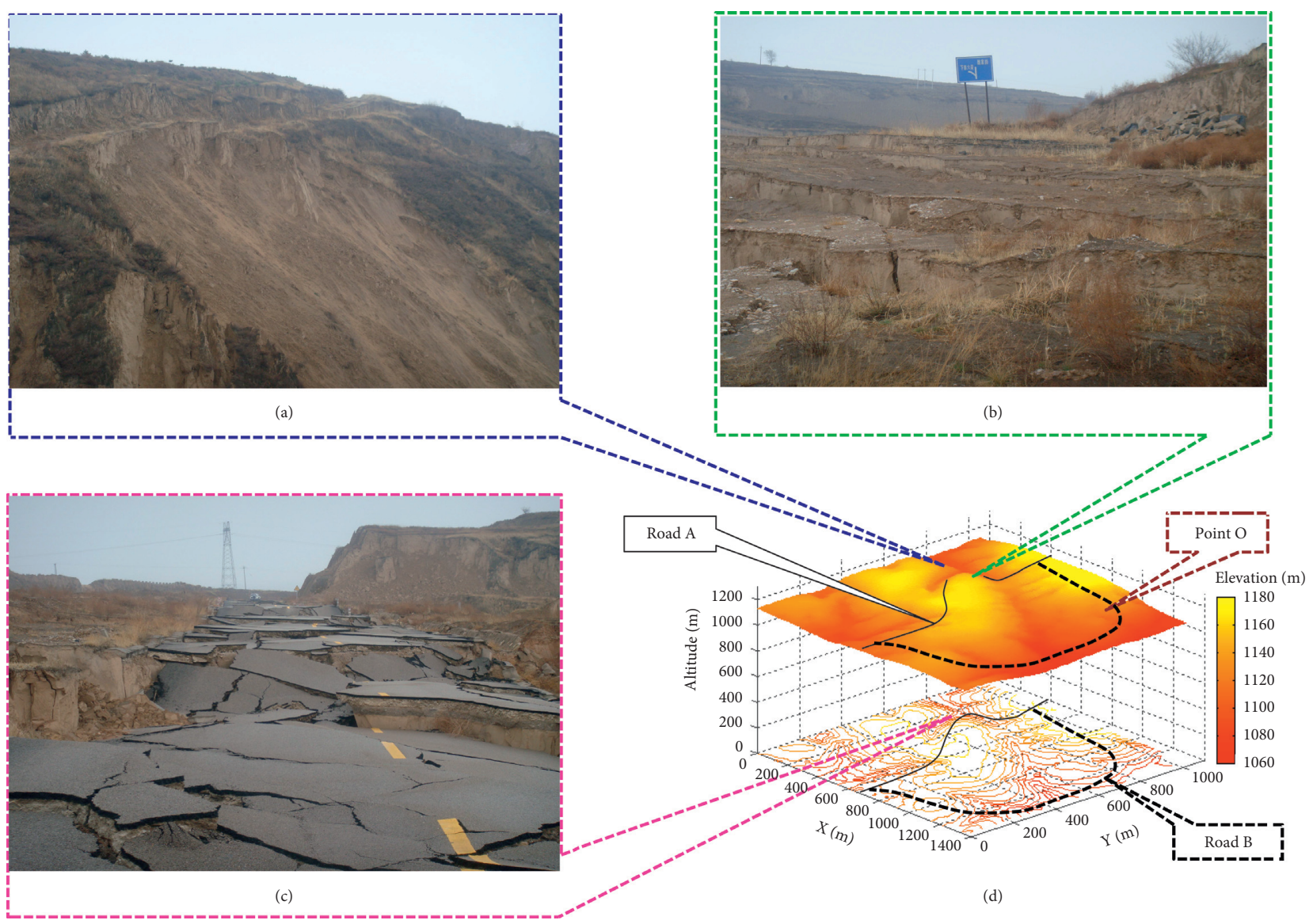

FIgURE 2: Surface subsidence and destruction in the mining area. (a) Large area geological landslide. (b) Large area surface subsidence. (c) Road destruction. (d) Surface topography of mining area.
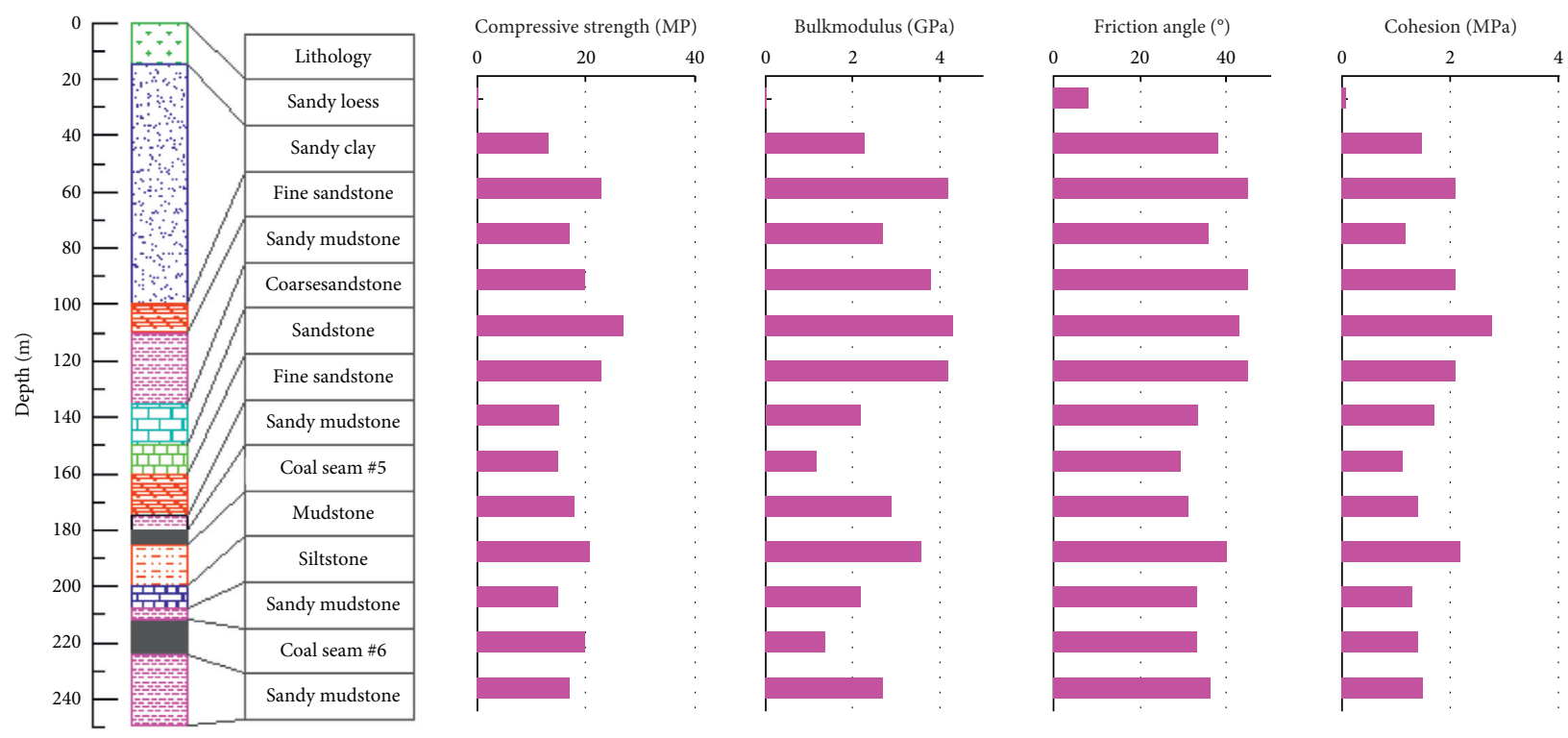

Figure 3: Borehole columnar section (point O).

(1) The side of the model is a rolling branch, which is used to limit the horizontal movement.

(2) The lower boundary of the model is defined as a fullconstraint boundary, which is used to limit horizontal and vertical displacements.
(3) The upper boundary of the model, defined as the free boundary, is the loess layer, and the horizontal and vertical directions are relatively large.

The compaction of caving gangue in goaf has an important influence on the surface subsidence and the 


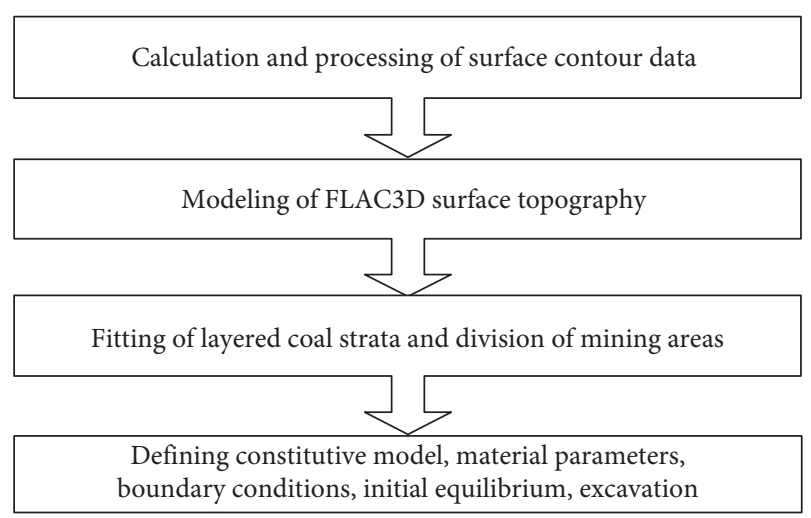

Figure 4: The flowchart of the model generation.

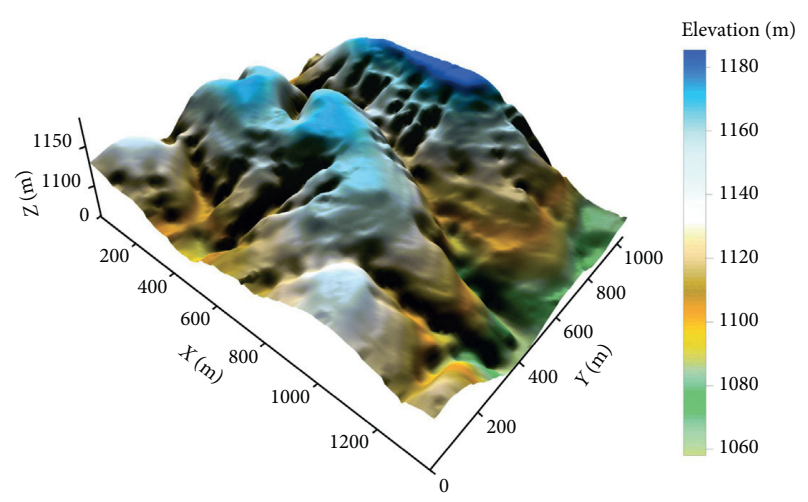

FIGURE 5: Surface three-dimensional topographic map.

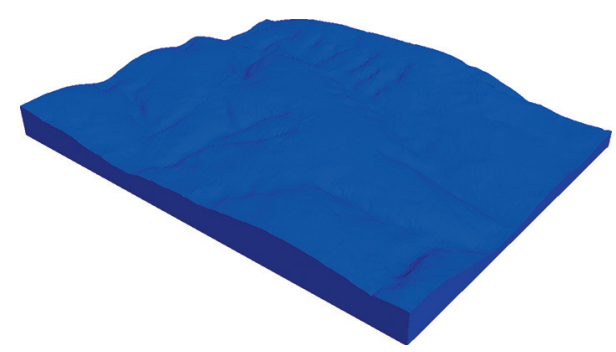

FIgURE 6: Three-dimensional model generated by a hexahedral element above an elevation of $883 \mathrm{~m}$.

distribution of mining stress. The mining coal seam is shallow (depth less than $200 \mathrm{~m}$ ), the mining thickness of the coal seam is large at one time (mining thickness is $12.8 \mathrm{~m}$ ), and the overlying strata are mostly weakly cemented strata. Thus, the empty unit is used to simulate the goaf state in the numerical simulation. This approach can better reflect the actual conditions of coal seam mining.

In the simulation experiment using the Mohr-Coulomb model, the initial stress field needed to be calculated. Because the numerical simulation study area is shallow and there is no geological structure, the original rock stress is mainly caused by the self-weight of the rock mass. Considering the overall in situ stress distribution in the study area and the effect of the surface gullies, the horizontal stress is 1.1 times the vertical stress [25].
According to the measured results, the basic expression of the stress of the original rock in the three directions of the mining area is as follows:

$$
\left\{\begin{array}{l}
\sigma_{1}=1.1 \rho g h, \\
\sigma_{2}=1.1 \rho g h, \\
\sigma_{3}=\rho g h .
\end{array}\right.
$$

In this equation, $\rho$ is the average rock mass of $2,550 \mathrm{~kg} /$ $\mathrm{m}^{3}, g=10 \mathrm{~N} / \mathrm{kg}$, and $h$ is the depth of burial (the elevation difference from the surface level to a certain point).

3.2. Material Properties. The numerical calculation was performed using the Mohr-Coulomb failure criterion. The material parameters of the Mohr-Coulomb model included cohesion, internal friction angle, bulk modulus, Poisson's ratio, bulk modulus compressive strength, and tensile strength. The physical and mechanical parameters of the rock formations are shown in Figure 3 and Table 3.

An initial equilibrium state was achieved after model establishment, and the vertical stress distribution of the seam and layers under the influence of the gully terrain is shown in Figure 7 (c). The effect of the gully terrain on the in situ stress field is significant. The degree of the effect decreases with increasing depth of the gully. The vertical stress distribution in Seam no. 6 is shown in Figure $7(\mathrm{~d})$. The vertical stress contour in the coal seam is similar to that in the surface contour. Thus, the gully terrain has an impact on the mining of Seam \#6.

\section{Geological Hazard-Prone Area in the Mining Area}

The mining area is covered by thick, sticky loess with poor mechanical properties. The coal seam overburden mainly consists of sandstone and sandy mudstone with low mechanical strength. The geological conditions in the mining area are simple and have no obvious geological structure. Because of the large size of the excavation area and the lower depth of the coal seam, the main influencing factor of mining pressure is vertical stress under gully influence. As a result of the mining process, collapse of the overlying strata was observed and led to the subsidence phenomena, as shown in Figure 2. Surface deformation and destruction were mainly caused by the increase in the shear strength during the mining process.

According to the Mohr-Coulomb criterion, the primary cause of slope landslide is the shear stress on the surface reaching a threshold shear strength and disrupting the equilibrium state. The shear stress $\tau$ at a certain point can be calculated by the maximum principal stress and the minimum principal stress at this point:

$$
t=\frac{\sigma_{1}-\sigma_{3}}{2} \sin 2 \beta
$$

In the formula, $\sigma_{1}$ is the maximum principal stress at a given point, $\mathrm{MPa} ; \sigma_{3}$ is the minimum principal stress at a given point, $\mathrm{MPa}$; and $\beta$ is the angle of the shear stress $\tau$ acting face and maximum principle stress $\sigma_{1}$ acting face, ${ }^{\circ}$. 


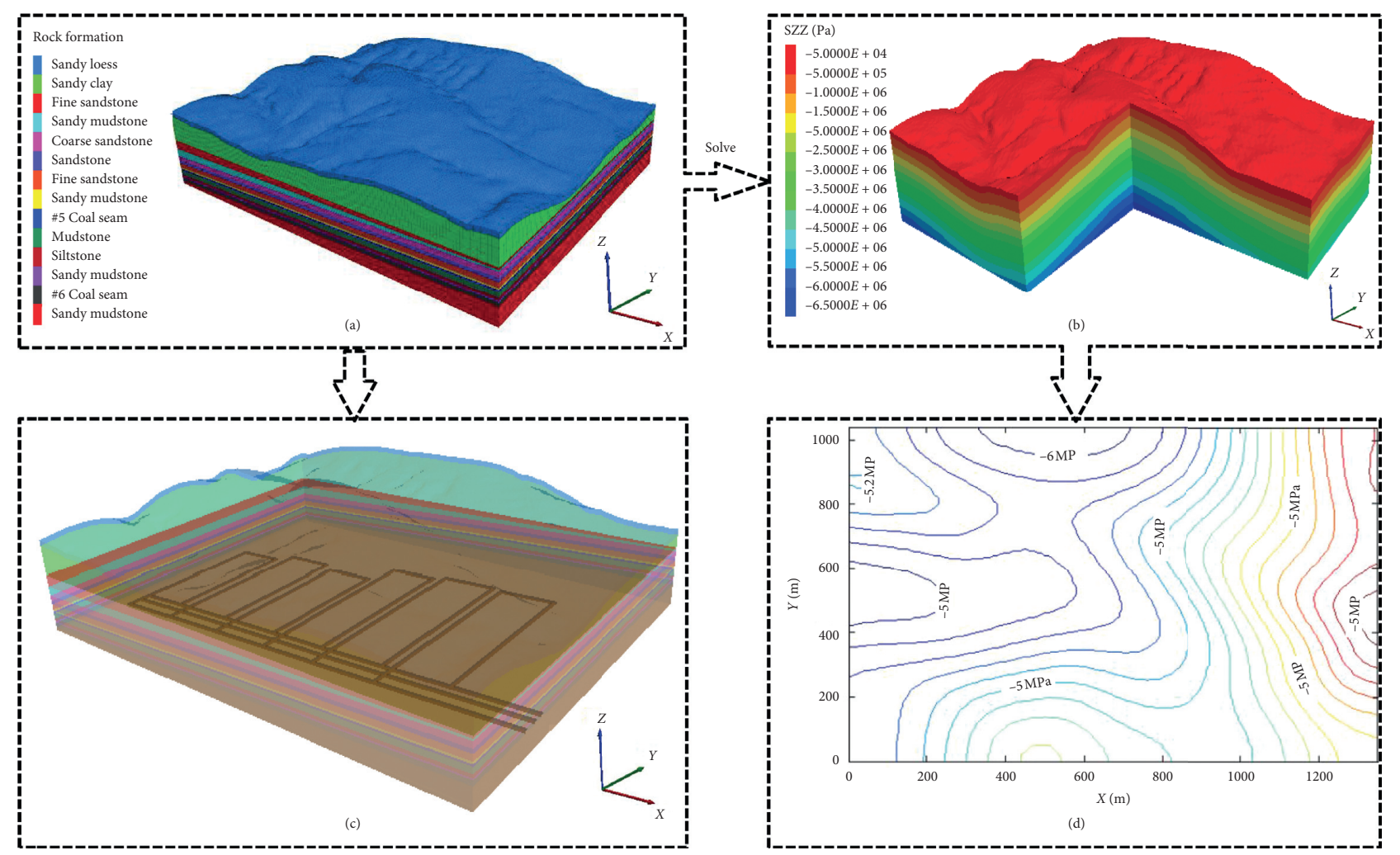

Figure 7: Three-dimensional modeling and in situ stress distribution. (a) Numerical model. (b) In situ stress distribution. (c) Underground roadways and mining area. (d) Stress distribution of coal seam.

TABLE 2: Dimension parameters of the working face in the calculation model.

\begin{tabular}{|c|c|c|c|c|c|c|c|}
\hline \multirow[t]{2}{*}{ Working face number } & \multicolumn{4}{|c|}{ Actual mining range of the working face } & \multicolumn{3}{|c|}{$\begin{array}{l}\text { Mining area in the } \\
\text { calculation model }\end{array}$} \\
\hline & Face length $(\mathrm{m})$ & Mining length $(\mathrm{m})$ & Mining height $(\mathrm{m})$ & Mining speed $\left(\mathrm{m} \cdot \mathrm{d}^{-1}\right)$ & $\mathrm{X}(\mathrm{m})$ & $\mathrm{Y}(\mathrm{m})$ & $\mathrm{Z}(\mathrm{m})$ \\
\hline 6206 & 150 & 385 & 12.8 & 2.1 & $60-210$ & $300-680$ & $14-22$ \\
\hline 6205 & 160 & 420 & 12.8 & 1.4 & $230-390$ & $300-720$ & $14-22$ \\
\hline 6204 & 160 & 390 & 12.8 & 1.4 & $410-570$ & $300-690$ & $14-22$ \\
\hline 6203 & 150 & 460 & 12.8 & 2.1 & $590-740$ & $300-760$ & $14-22$ \\
\hline 6202 & 180 & 480 & 12.8 & 1.2 & $760-940$ & $300-780$ & $14-22$ \\
\hline 6201 & 170 & 470 & 12.8 & 1.4 & $960-1130$ & $300-770$ & $14-22$ \\
\hline
\end{tabular}

When $\beta=45^{\circ}$, according to formula (1), the maximum shear stress is

$$
\tau_{\max }=\frac{\sigma_{1}-\sigma_{3}}{2}
$$

The shear stress distribution of the surface gully slope is shown in Figure 8.

The maximum shear stress was concentrated from the slope top to the gully bottom. The stress concentration increased with increasing slope angle, indicating a threat for landslides. The probability increases with increasing slope angle. Landslide, collapse, and other geological hazards occur on the acting face of maximum shear stress because of the disruption of the stress equilibrium state during mining activities. To avoid the occurrence of surface geological disasters, the variation in the stress field and displacement field should be given greater attention.

\section{Effect of Mining Activity on the Surface Stress and Displacement Field Changes}

Seam no. 6 working face in the three-dimensional model (Figure 7(a)) was successively mined. The mining sequence of Seam no. 6 was as follows: working face $6206 \longrightarrow$ working face $6205 \longrightarrow$ working face $6204 \longrightarrow$ working face $6203 \longrightarrow$ working face $6202 \longrightarrow$ working face 6201 . Working face mining is a dynamic process. The mining speed not only affects the instability movement characteristics of overlying rock, the appearance of working face mineral pressure, and the bearing characteristics of the support, but also dynamically influences the surface subsidence and destruction [42]. Considering the actual propulsion speed of the working face (Table 2), each working face was designed for multiple circular excavations in the numerical calculation, where each excavation cycle was $1.5 \mathrm{~m}$ and the cycle time step was 2000 steps. The distributions of the stress field, 
TABle 3: Physical and mechanical parameters of the rock formations.

\begin{tabular}{|c|c|c|c|c|c|c|c|c|}
\hline $\begin{array}{l}\text { Serial } \\
\text { number }\end{array}$ & Lithology & $\begin{array}{l}\text { Volume } \\
\text { weight } \\
\left(\mathrm{kg} \cdot \mathrm{m}^{-3}\right) \\
\end{array}$ & $\begin{array}{c}\text { Bulk } \\
\text { modulus } \\
(\mathrm{GPa})\end{array}$ & $\begin{array}{l}\text { Poisson's } \\
\text { ratio }\end{array}$ & $\begin{array}{l}\text { Compressive } \\
\text { strength }(\mathrm{MPa})\end{array}$ & $\begin{array}{c}\text { Tensile } \\
\text { strength } \\
(\mathrm{MPa}) \\
\end{array}$ & $\begin{array}{l}\text { Cohesion } \\
(\mathrm{MPa})\end{array}$ & $\begin{array}{c}\text { Internal } \\
\text { friction angle } \\
\left({ }^{\circ}\right)\end{array}$ \\
\hline 1 & Sandy loess & 2270 & 0.01 & 0.24 & 0.16 & 0.03 & 0.01 & 13 \\
\hline 2 & Sandy clay & 2360 & 2.3 & 0.22 & 13 & 1.7 & 1.5 & 38 \\
\hline 3 & $\begin{array}{c}\text { Fine } \\
\text { sandstone }\end{array}$ & 2500 & 4.2 & 0.30 & 23 & 1.6 & 2.1 & 45 \\
\hline 4 & $\begin{array}{l}\text { Sandy } \\
\text { mudstone }\end{array}$ & 2650 & 2.7 & 0.26 & 17 & 1.2 & 1.2 & 36 \\
\hline 5 & $\begin{array}{c}\text { Coarse } \\
\text { sandstone }\end{array}$ & 2560 & 3.8 & 0.19 & 20 & 1.9 & 2.1 & 45 \\
\hline 6 & Sandstone & 2500 & 4.3 & 0.25 & 27 & 2.0 & 2.8 & 43 \\
\hline 7 & $\begin{array}{c}\text { Fine } \\
\text { sandstone }\end{array}$ & 2550 & 4.2 & 0.30 & 23 & 2.1 & 2.1 & 45 \\
\hline 8 & $\begin{array}{l}\text { Sandy } \\
\text { mudstone }\end{array}$ & 2600 & 2.2 & 0.23 & 15 & 1.4 & 1.7 & 33 \\
\hline 9 & $\begin{array}{l}\text { Coal Seam } \\
\text { no. } 5\end{array}$ & 1400 & 1.2 & 0.35 & 15 & 1.3 & 1.1 & 29 \\
\hline 10 & Mudstone & 2500 & 2.9 & 0.21 & 18 & 1.7 & 1.4 & 31 \\
\hline 11 & Siltstone & 2600 & 3.6 & 0.26 & 21 & 2.1 & 2.2 & 40 \\
\hline 12 & $\begin{array}{l}\text { Sandy } \\
\text { mudstone }\end{array}$ & 2600 & 2.2 & 0.23 & 15 & 1.7 & 1.3 & 33 \\
\hline 13 & $\begin{array}{l}\text { Coal Seam } \\
\text { no. } 6\end{array}$ & 1380 & 1.4 & 0.33 & 20 & 1.4 & 1.4 & 33 \\
\hline 14 & $\begin{array}{l}\text { Sandy } \\
\text { mudstone }\end{array}$ & 2650 & 2.7 & 0.28 & 17 & 1.6 & 1.5 & 36 \\
\hline
\end{tabular}

displacement field, and surface damage after mining of working faces 6205, 6203, and 6201 are shown in Figures 9-11, respectively.

After the mining of working face 6205 , the surface shear stress concentration appeared above the mined-out area, and the stress concentration reached a maximum value (1.0 MPa) near the gully slope. The probability of large-scale geological landslides in the gully slope increased as a result of coal seam mining. The surface displacement contour (maximum displacement value: $5.0 \mathrm{~m}$ ) and plastic failure zone were distributed in an "O" shape (Figures 9(c) and 9(d)). Different degrees of collapse occurred, and the maximum surface collapse occurred in the middle of the goaf.

After the mining of working face 6203, the shear stress concentration increased, and the maximum value reached 1.4 $\mathrm{MPa}$ (Figure 10(b)). When the overlying strata became steady, the plastic failure zone was distributed in an inverted "C" shape. The plastic failure zone was distributed on the side of the unexploited seam (Figure 10(c)). Plastic damage in the gully slope at the edge of the mined-out area affected the stability of surface buildings and roads. When the mined-out area became approximately square, the ground displacement contour was expanded from an "O" shape to an approximate square (Figure 10(d)).

After the mining of working face 6201, the surface shear stress concentration area (Figure 11(b)), plastic failure area (Figure 11(c)), and surface displacement contour (Figure 11(d)) reached maximum values. The maximum shear stress increased to $1.5 \mathrm{MPa}$, the maximum surface subsidence was $10.0 \mathrm{~m}$, and the maximum values appeared near one side of working face 6201. The surface displacement values of working faces 6206 and 6205 did not increase with increasing mining area, indicating that the surface subsidence in this area tends to be stable.

A comprehensive analysis of Figures 9-11 shows that under the influence of mining stress, the overlying rock layer in the goaf area produces plastic damage, causing overlying rock instability movement and dynamic changes in the surface stress field and displacement field. In particular, the tension stress distribution area appears around the surface of the mining area, and surface deformation and destruction occur under tensional stress. Shear stress concentration occurs on the surface above the goaf area, and step subsidence occurs on the surface.

\section{Influence of Expanded Mining Range on the Dynamic Changes in Surface Damage}

With the sequential mining of each working face, the minedout area of Seam no. 6 constantly expanded. To analyze the dynamic influence of the expanding area on surface subsidence, the displacement curves of the slice $(Y=495 \mathrm{~m})$ along the mining sequence direction and the slices ( $X=310 \mathrm{~m}, X=490 \mathrm{~m}, X=660 \mathrm{~m}$, and $X=850 \mathrm{~m}$ ) along the advancing direction were examined. The dynamic changes in surface displacement are shown in Figures 12 and 13.

Figure 12 shows that the surface subsidence area and the maximum subsidence in the $X$-direction increased with the expansion of the mined-out area. The maximum subsidence value appeared in the mining of the working face. When the overlying strata movement became steady, the surface subsidence tended to be constant. The surface subsidence of $0-130 \mathrm{~m}$ in the $X$-direction tended to be stable during the exploitation of working face 6205 . The surface subsidence of 


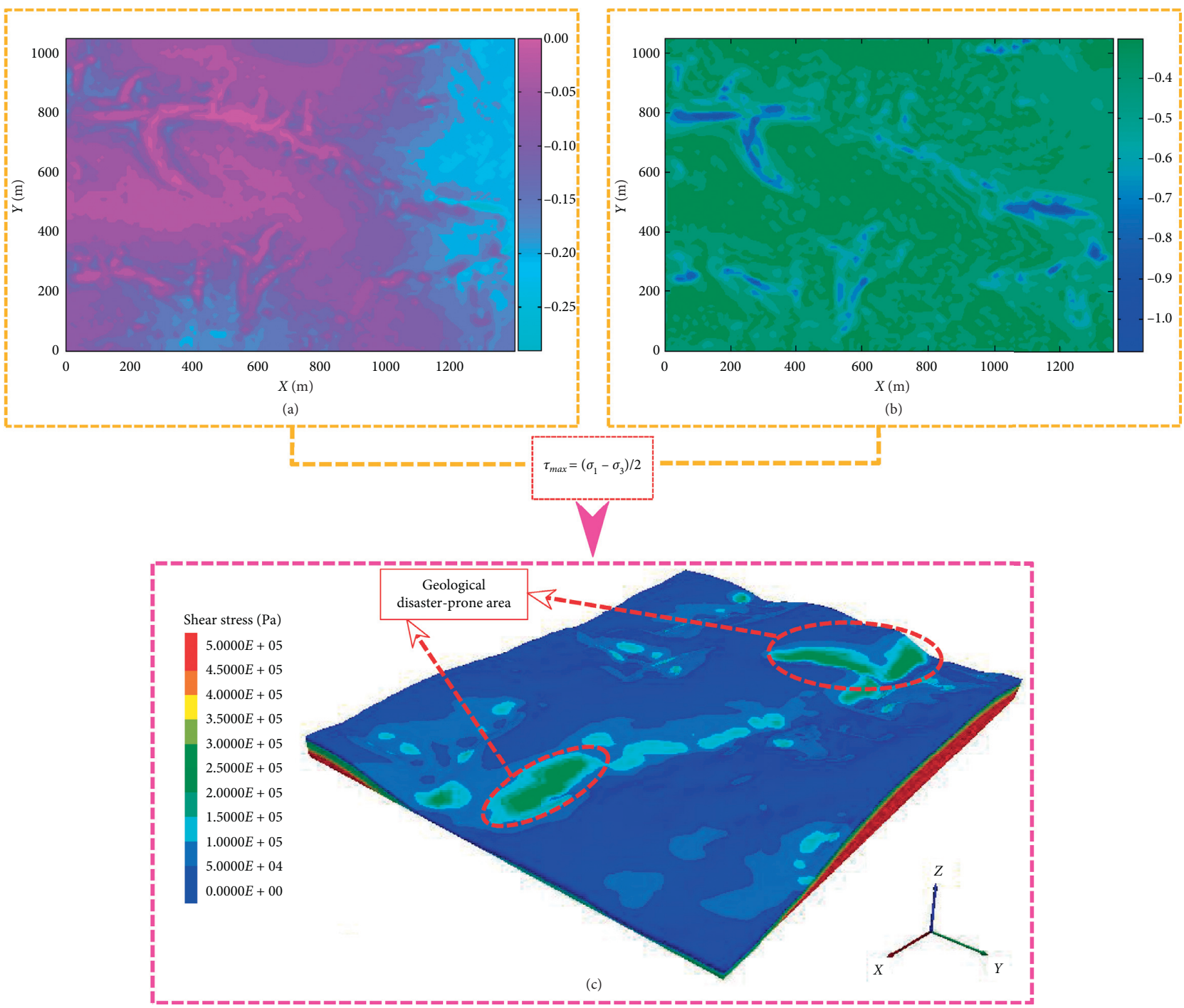

Figure 8: Shear stress distribution of the surface gully slope. (a) Maximum principal stress $\left(\sigma_{1}\right) / \mathrm{MPa}$. (b) Minimum principal stress $\left(\sigma_{3}\right) /$ MPa. (c) Maximum shear stress.

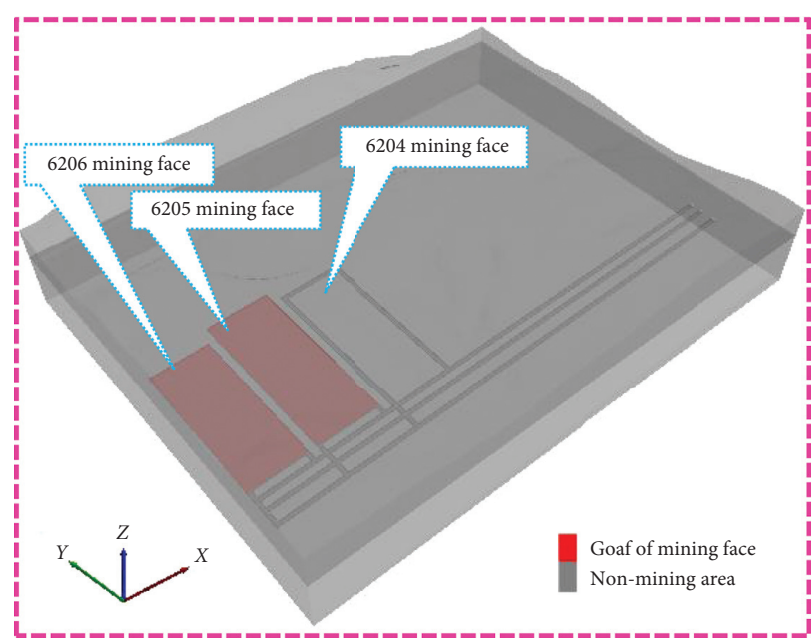

(a)

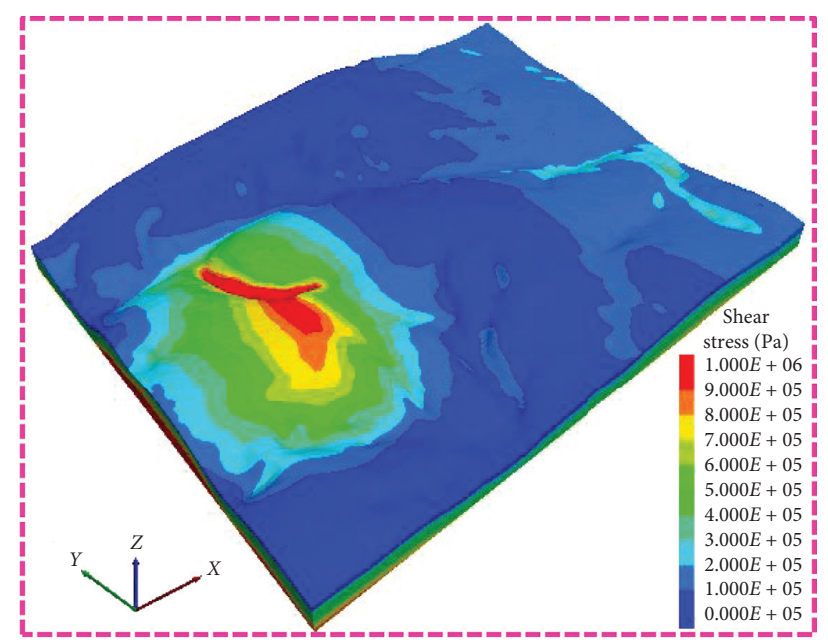

(b)

Figure 9: Continued. 


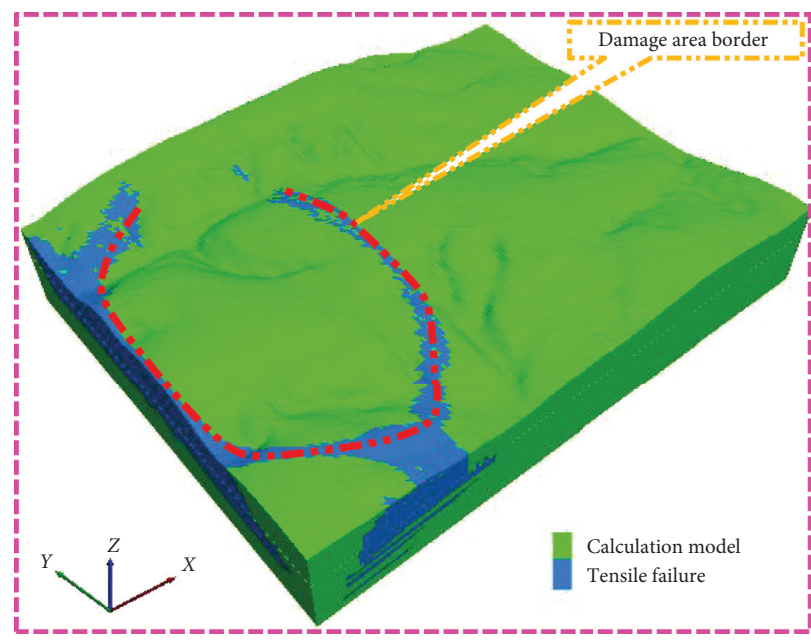

(c)

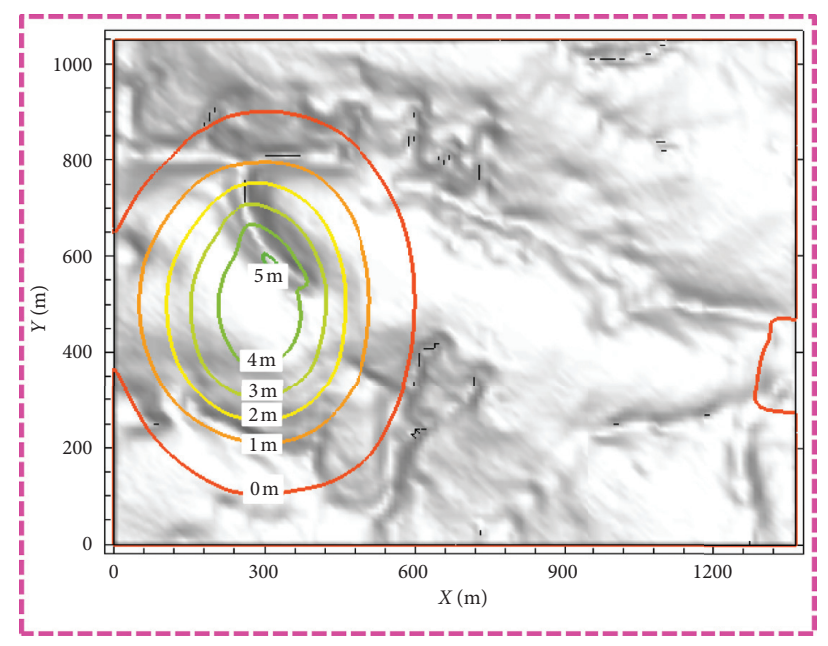

(d)

FIGURE 9: Distribution of the stress field, displacement field, and surface damage after mining of working face 6205. (a) Calculation model. (b) Maximum shear stress. (c) Region of surface damage. (d) Surface displacement contours.

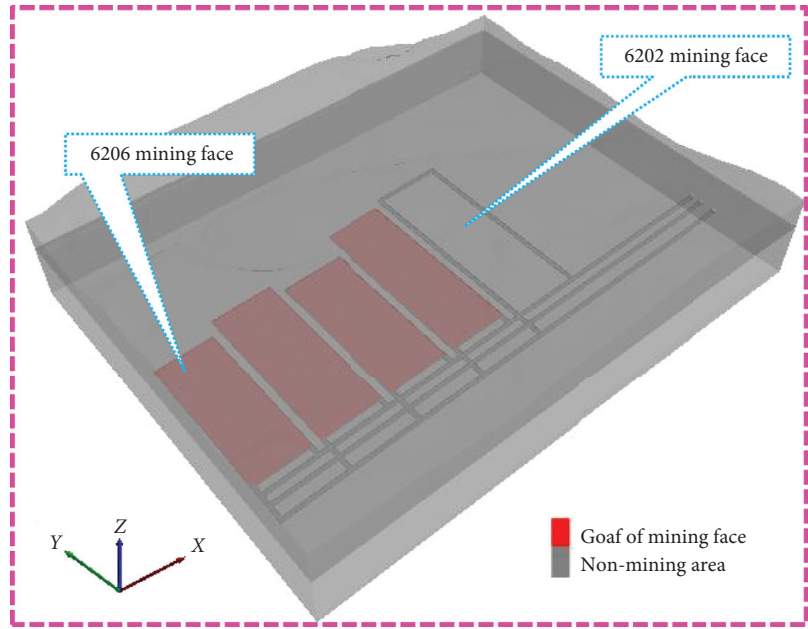

(a)

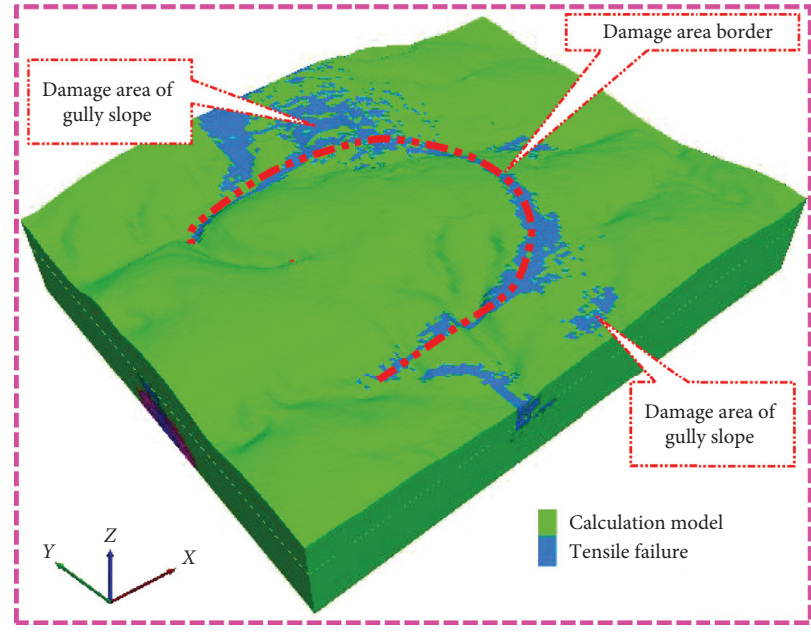

(c)

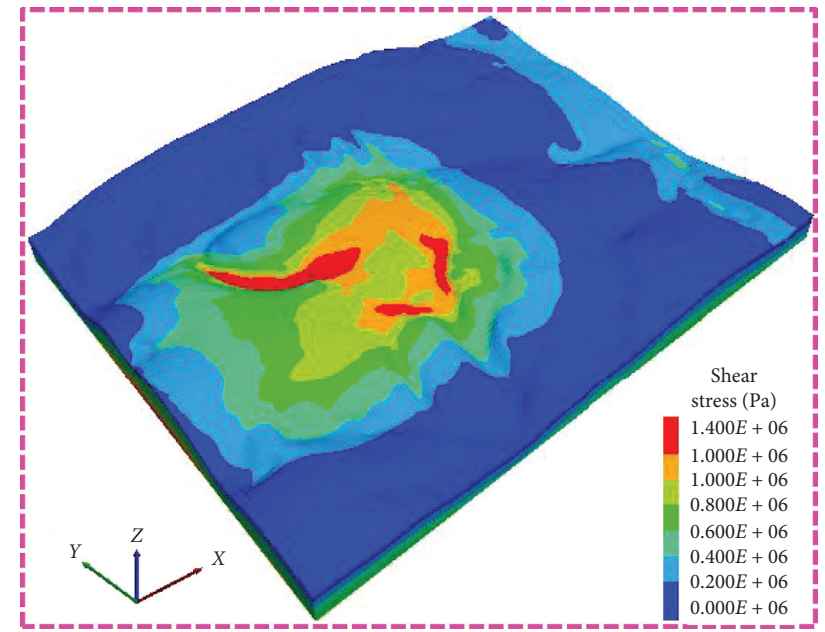

(b)

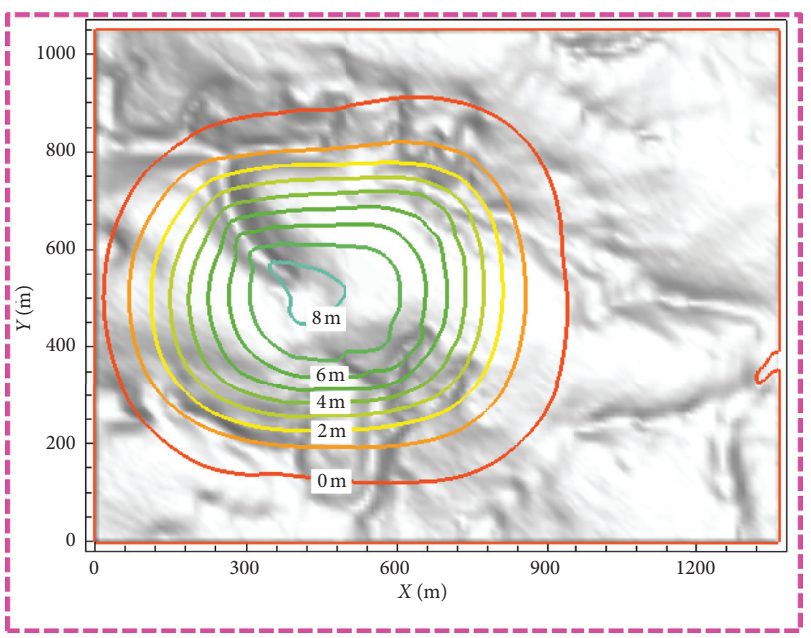

(d)

FIGURE 10: Distribution of the stress field, displacement field, and surface damage after mining of working face 6203. (a) Calculation model. (b) Maximum shear stress. (c) Region of surface damage. (d) Surface displacement contours. 


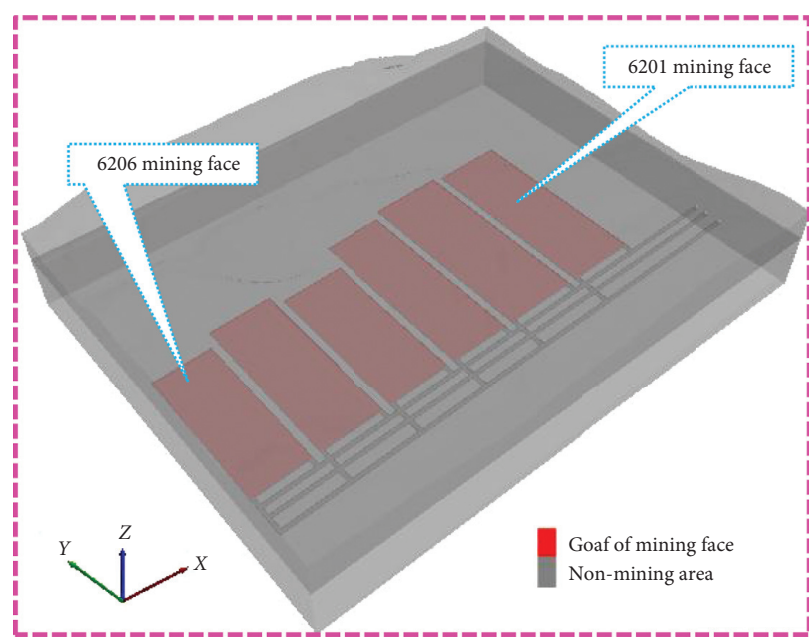

(a)

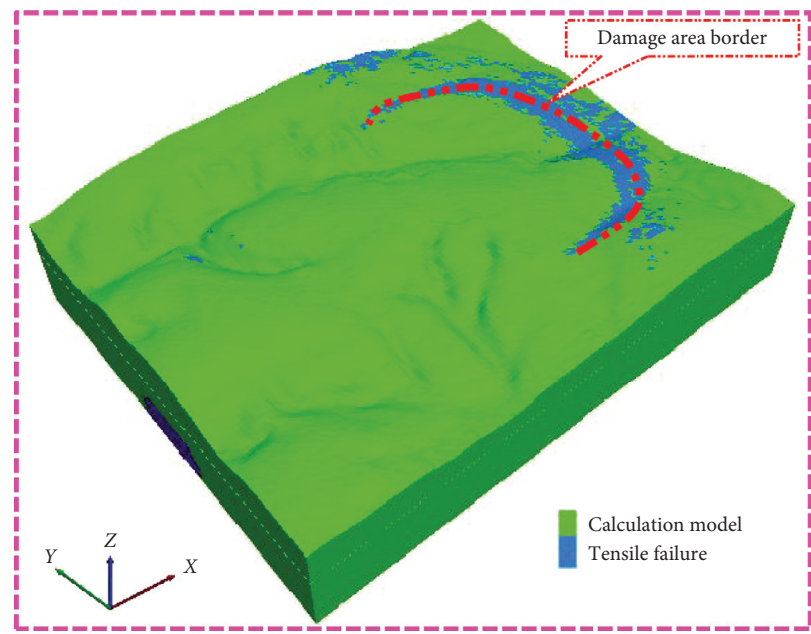

(c)

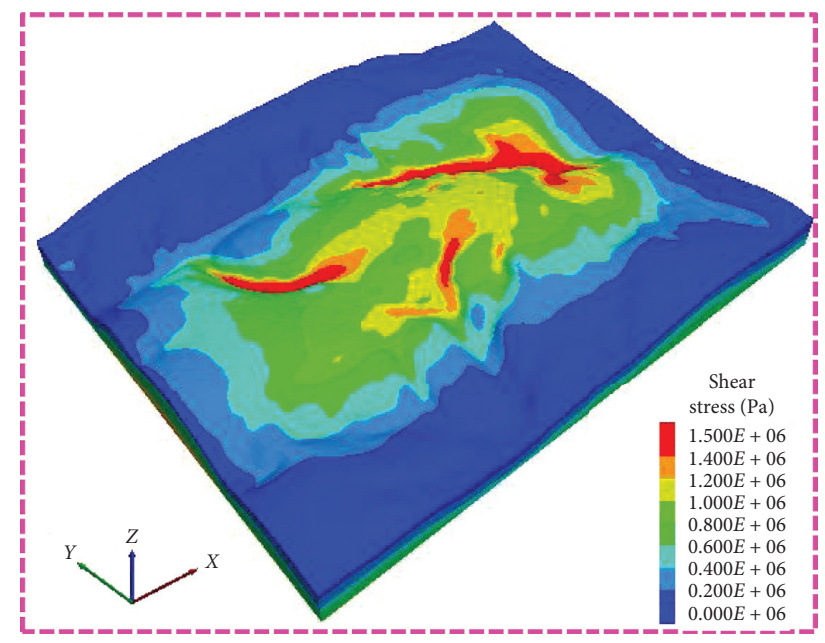

(b)

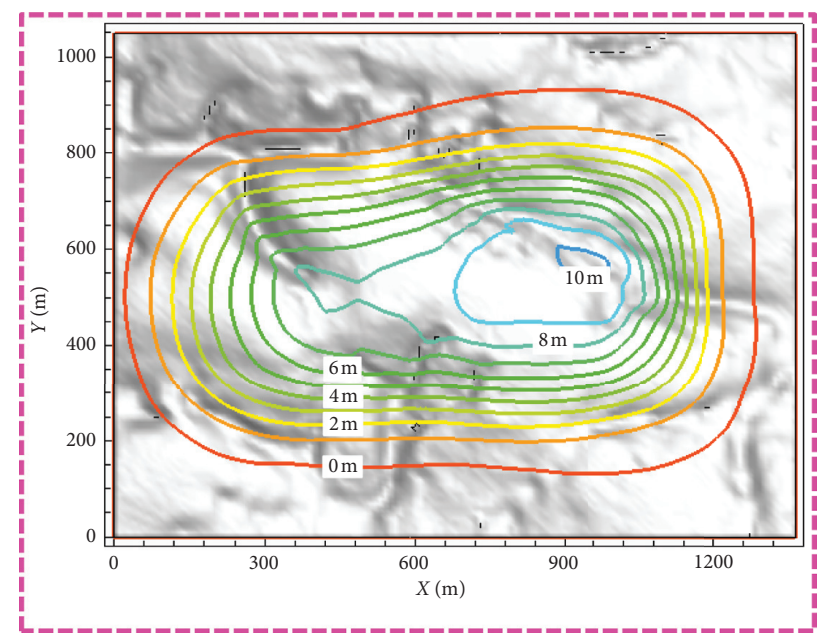

(d)

Figure 11: Distribution of the stress field, displacement field, and surface damage after mining of working face 6201. (a) Calculation model. (b) Maximum shear stress. (c) Region of surface damage. (d) Surface displacement contours.

$0-240 \mathrm{~m}$ in the $X$-direction tended to be stable during the exploitation of working face 6204. The surface subsidence of $0-310 \mathrm{~m}$ in the $X$-direction tended to be stable during the exploitation of working face 6203 . The surface subsidence of $0-360 \mathrm{~m}$ in the $X$-direction tended to be stable during the exploitation of working face 6202 . The surface subsidence of $0-380 \mathrm{~m}$ in the $X$-direction tended to be stable during the exploitation of working face 6201.

Figure 13 shows that the surface subsidence area in the $Y$-direction was basically unchanged after the mining of each working surface. The surface subsidence value gradually increased from the edge of the mined-out area to the middle. The maximum subsidence value generally appeared in the middle of the mined-out area. Due to the compaction of caving gangue, the surface subsidence of the previous working face was unchanged when the subsequent working face was excavated.

The surface subsidence area was larger than the goaf range [43-45]. With the continuous expansion of the coal mining area, the dynamic changes of surface subsidence are of great importance to the prediction of mining damage and the evaluation of surface geological hazards. To analyze the dynamic changes in the surface subsidence influence area with constant expansion of the mined-out area, assuming that the ratio of the maximum impact range of surface subsidence $\left(S_{\max }\right)$ and the mined-out area $\left(s_{\max }\right)$ is the amplification ratio $\eta$ of the surface influence range, then

$$
\eta=\frac{S_{i \max }}{s_{i \max }}
$$

In this formula, $S_{i \max }$ is surface subsidence influence area after working face $i$ is mined out, $\mathrm{m}^{2} ; s_{i \max }$ is goaf area after working face $i$ is mined out, $\mathrm{m}^{2}$.

The amplification ratio $\eta$ can show the trend of surface movement and deformation of the adjacent working face under the influence of the goaf and the dynamic change of surface subsidence with the continuous expansion of the coal mining area. The dynamic change curve of the amplification ratio $\eta$ after each working face is mined out is shown in Figure 14. The 


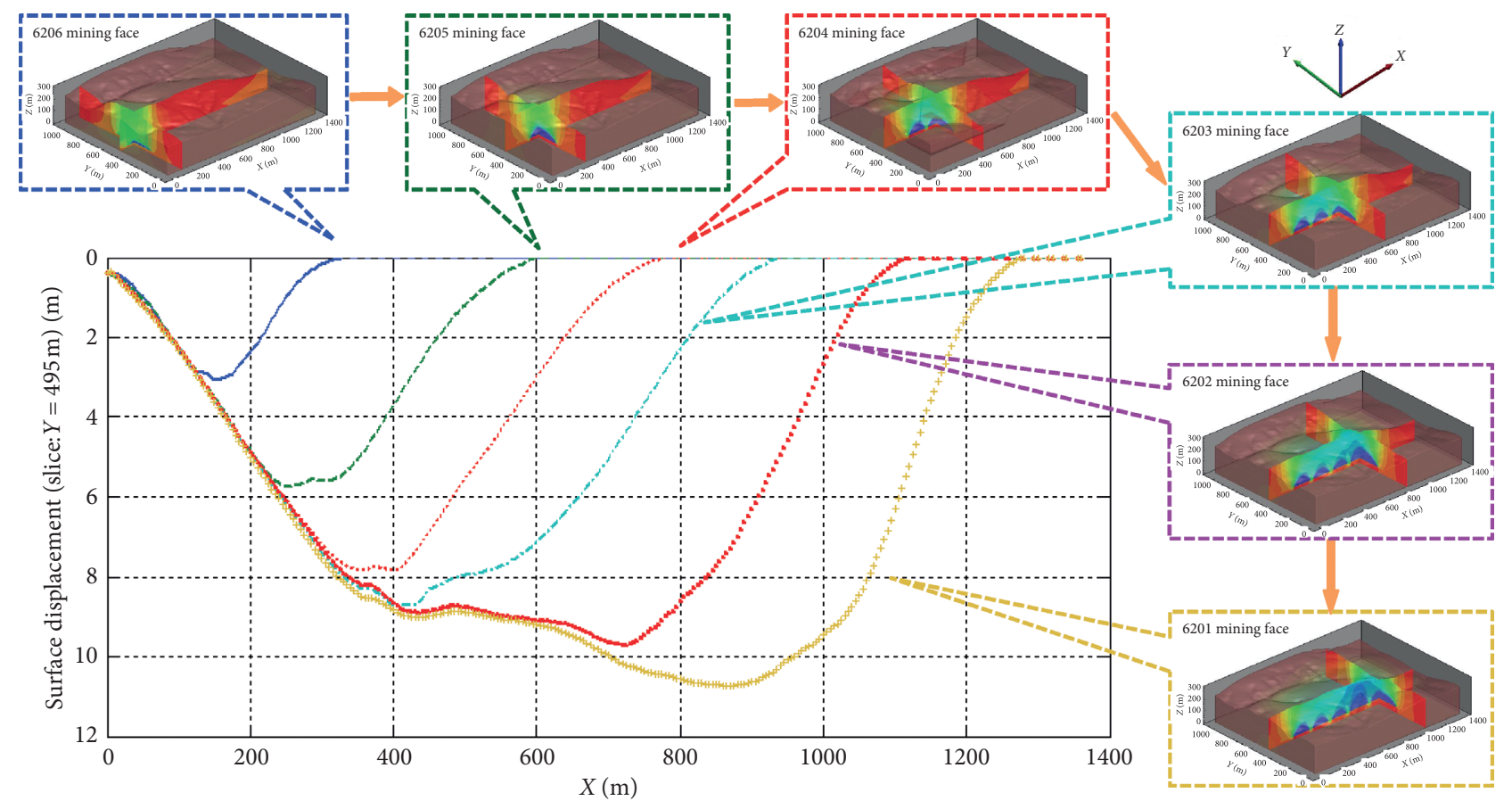

FIGURE 12: Dynamic changes in overburden and surface displacement with expansion of the coal seam mined-out area $(Y=495 \mathrm{~m})$.

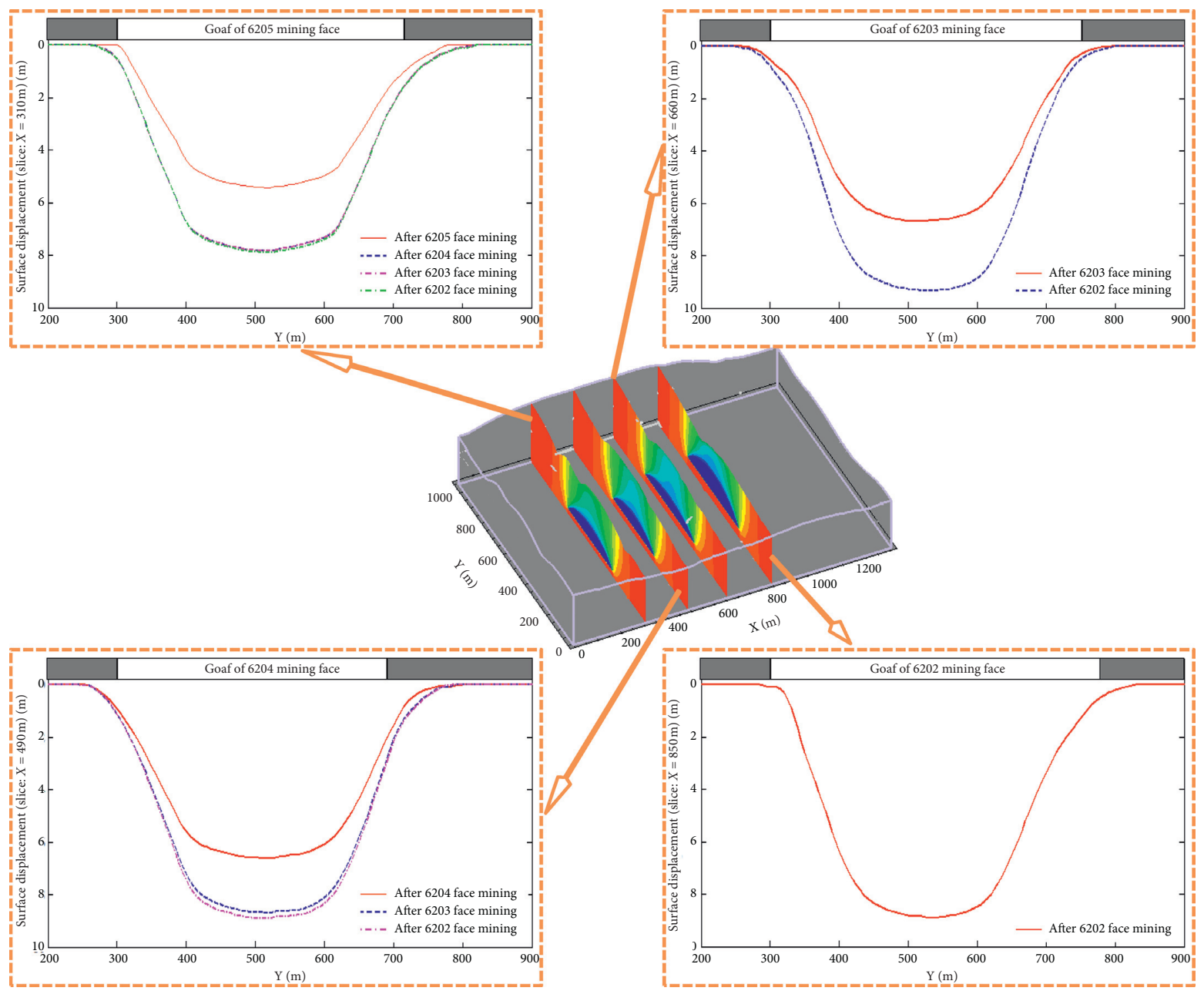

FIGURE 13: Dynamic changes in overburden and surface displacement with expansion of the coal seam mined-out area $(X=310 \mathrm{~m}, 490 \mathrm{~m}$, $660 \mathrm{~m}$, and $850 \mathrm{~m})$. 


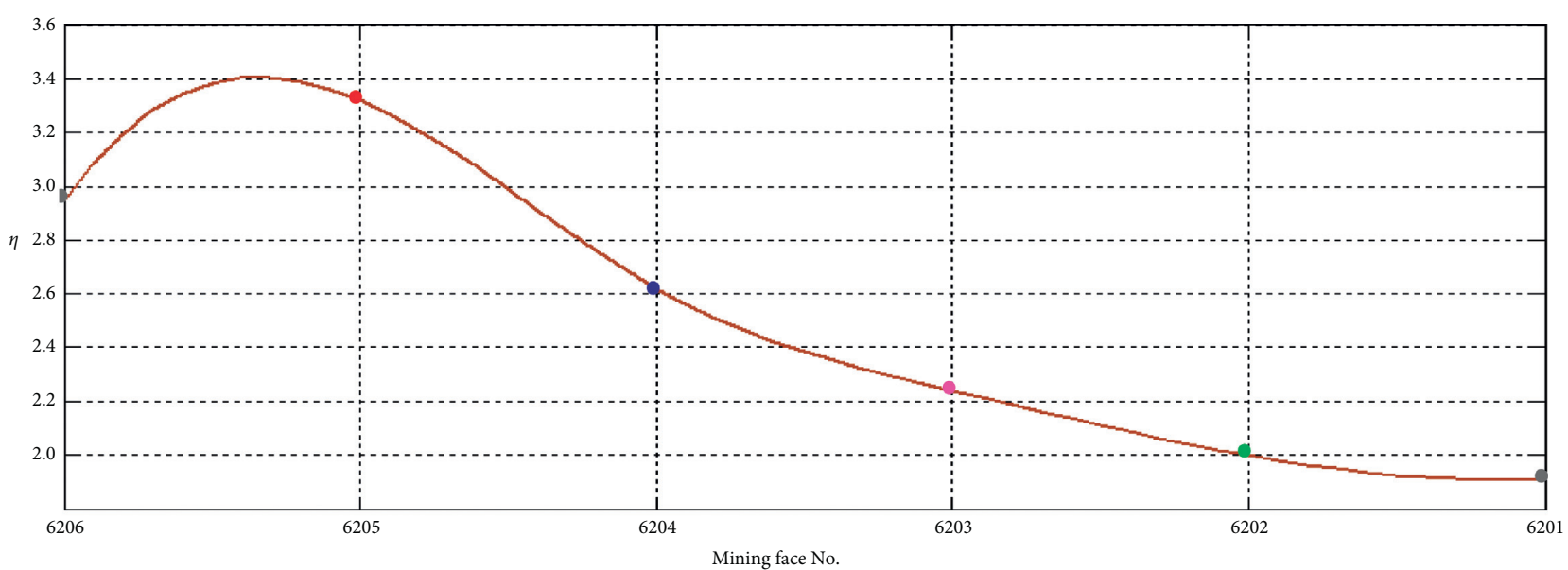

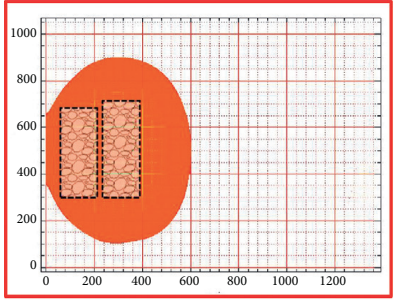

After 6205 face mining

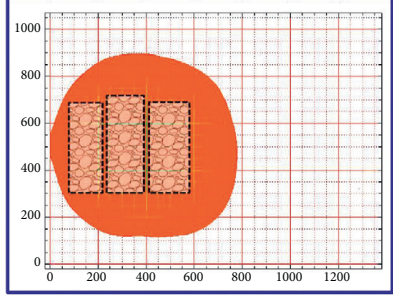

After 6204 face minin

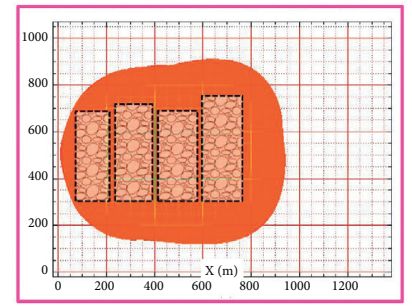

After 6203 face minin

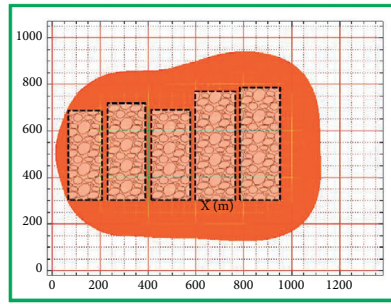

After 6202 face mining

Surface plastic failure zone Gzoaf of mining face

FIgURE 14: Change curve of amplification ratio $\eta$ after each working face was mined out.

Table 4: Angle parameters of static surface movement.

\begin{tabular}{lcccc}
\hline Direction & $\begin{array}{c}\text { Angle of draw } \\
\left({ }^{\circ}\right)\end{array}$ & $\begin{array}{c}\text { Angle of critical } \\
\text { deformation }\left(^{\circ}\right)\end{array}$ & $\begin{array}{c}\text { Average value (angle of } \\
\text { draw) }\left({ }^{\circ}\right)\end{array}$ & $\begin{array}{c}\text { Average value (angle of critical } \\
\text { deformation) }\left({ }^{\circ}\right)\end{array}$ \\
\hline $\begin{array}{l}\text { Mining line } \\
\text { direction }\end{array}$ & $58.6-60.5$ & $59.8-62.7$ & 59.0 & 61.3 \\
Face line direction & $59.3-64.7$ & $67.1-69.4$ & 61.4 & 68.9 \\
\hline
\end{tabular}

surface subsidence area increased in an "O" shape after working face 6205 was mined out. The surface influence area was larger. The surface subsidence area expanded in the shape of an inverted " $\mathrm{C}$ " to the side of the unexploited coal seam on the basis of an "O" shape upon expansion of the mined-out area. The increasing amplitude of the surface influence area decreased as the denominator $S_{\text {imax }}$ in formula (3) constantly increases with the increasing mined-out area. The amplification ratio $\eta$ of surface damage first increased to a maximum, then decreased, and finally remained stable with the continuous expansion of coal seam mining. The analysis results have certain reference value for surface movement and deformation prediction, land reclamation, and ground building protection in mining areas under the conditions of repeated mining in adjacent working faces.

After the mining of working face 6206, the angular parameters of surface subsidence were measured and sorted, and the angular parameters of surface stabilization are shown in Table 4. The mining area of working face 6206 is $57,750 \mathrm{~m}^{2}$, and the average buried depth is $200 \mathrm{~m}$ The average amplification ratio $\eta$ of working face 6206 is 3.2 . The field measurement results are in good agreement with the numerical simulation results.

\section{Surface Influence in Geological Disaster- Prone Areas Induced by High-Intensity Mining of the Shallow, Thick Coal Seam in the Gully Area}

To analyze the dynamic changes in the surface subsidence area induced by high-intensity mining, the dynamic change in surface influence area after each working face was mined out was examined, as shown in Figure 15. The final surface subsidence influence area is $0-1280 \mathrm{~m}$ in the $X$-direction and $100-900 \mathrm{~m}$ in the $Y$-direction. Road $\mathrm{A}$ is in the subsidence influence area and was destroyed. Damage area $D$ was located at the edge of the mining subsidence of the working face. Tensional stress concentration occurs in the surface area, and surface deformation and destruction occur under tensile stress. The line selection of road B is located outside the influence area and was not affected by the collapse caused by seam mining. 


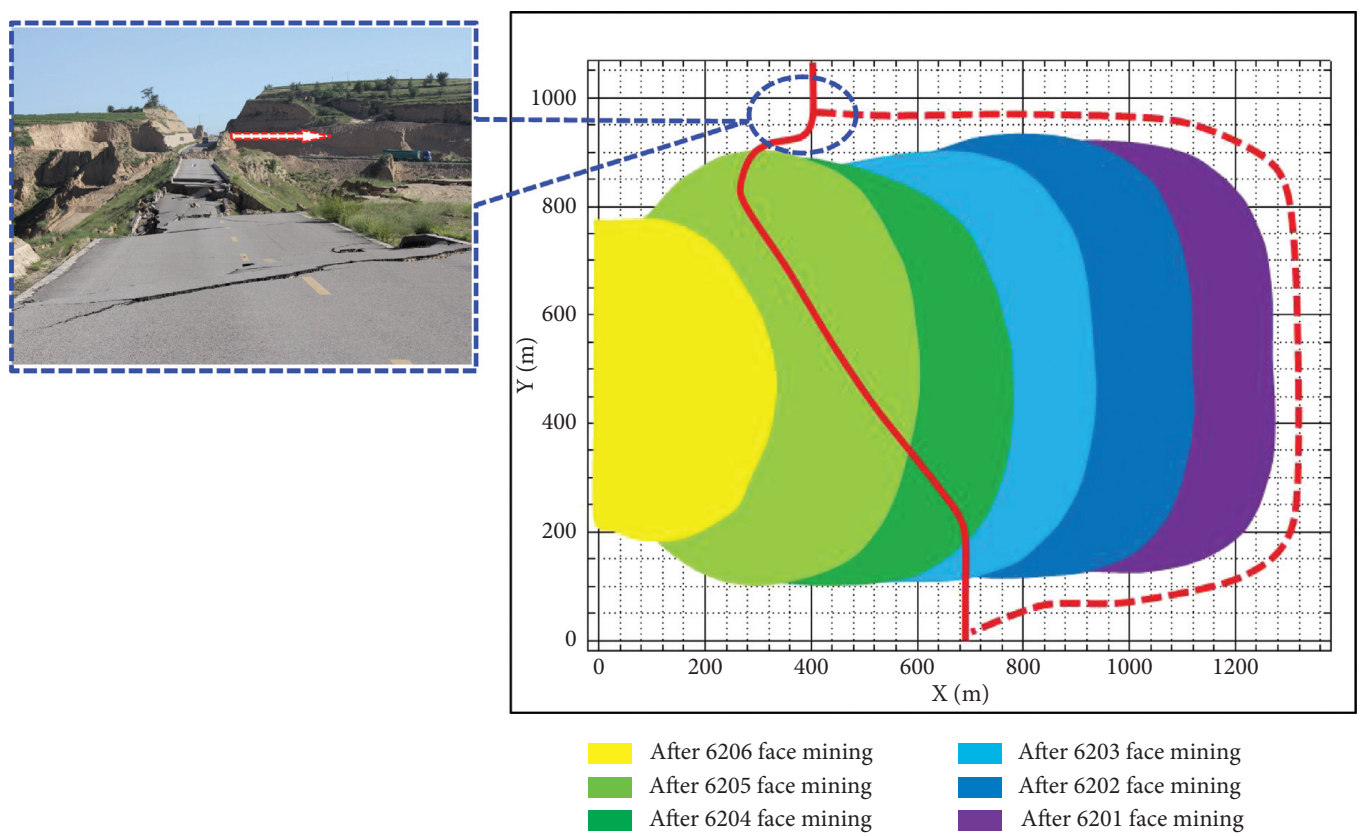

FIGURE 15: Dynamic changes in the surface influence area induced by high-intensity mining of the shallow, thick coal seam.
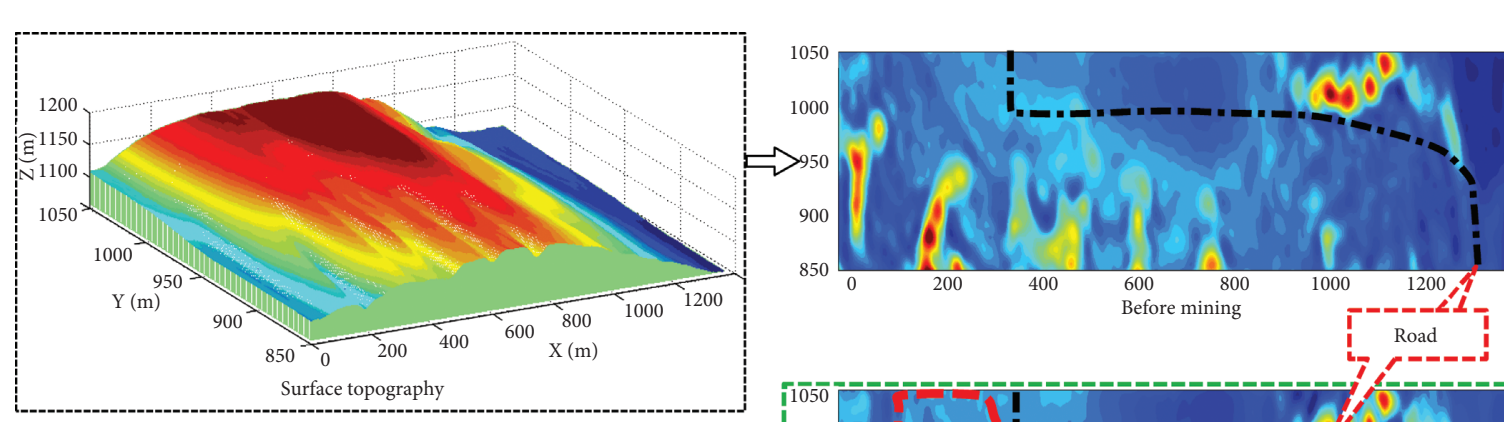

Shear stress

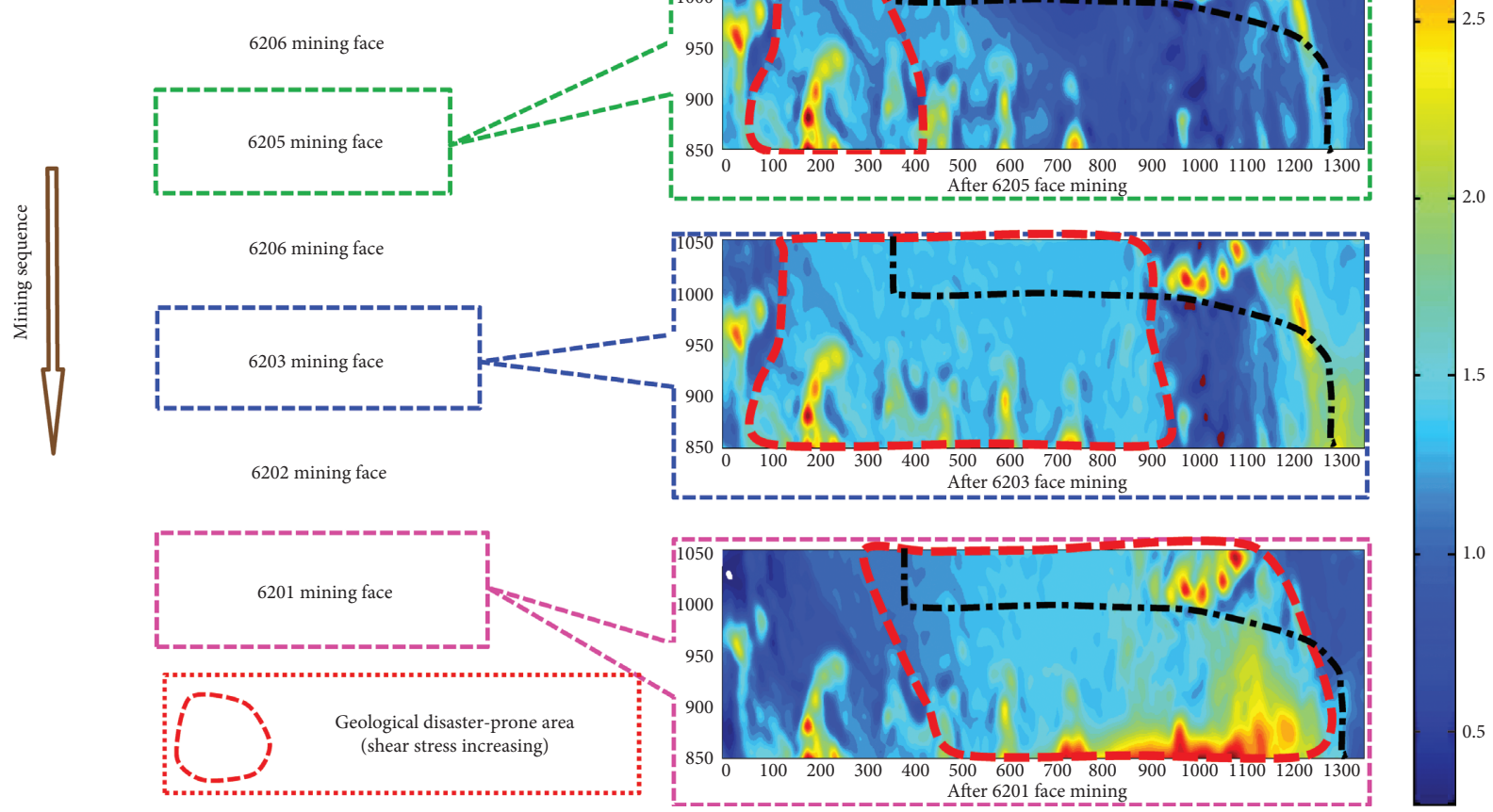

Figure 16: Dynamic changes in the maximum shear stress of the valley slope near road B after each working face was mined out. 
Because the line selection of road B is located in the gully slope (Figure $2(\mathrm{~d})$ ), the analysis of the stress distribution of the gully slope caused by seam mining is conducive to assessing gully slope stability and taking targeted measures to ensure that landslides, collapses, and other geological disasters do not occur. The dynamic changes in the maximum shear stress near road B after each working face is mined out are shown in Figure 16.

With the sequential mining of each working face, the maximum shear stress of the slope near surface road B increased to different degrees. The increasing range of shear stress changed dynamically with working face mining. Key monitoring and appropriate reinforcement of the slope should be adopted to ensure the stability of the slope according to the dynamic changes in the maximum shear stress near road $\mathrm{B}$.

In order to control the surface subsidence and surface damage of shallow coal seam mining in gully areas, mining technologies to reduce damaging ground fissures should be employed, including mining with narrow coal pillars, limited thickness extraction, backfill mining, and rapid advancing mining [46].

\section{Conclusions}

(1) The maximum shear stress is concentrated from the slope top to the gully bottom, indicating a threat of landslides. The probability of a landslide increases with increasing slope angle. Landslide, collapse, and other geological hazards occur on the acting face of maximum shear stress because of the disruption of the stress equilibrium state during mining activities.

(2) High-intensity mining activities exacerbate the concentration of maximum shear stress, which is more likely to cause landslides, collapses, and other geological disasters.

(3) The amplification ratio $\eta$ of surface damage first increases to a maximum, then decreases, and finally remains stable with the continuous expansion of coal seam mining. This ratio provides a scientific basis for the determination of the surface repair distance under the condition of high-intensity exploitation.

(4) The line selection of road B is located outside the influence area and will not be affected by the collapse caused by seam mining. However, the gully slope near road B is affected by seam mining. Key monitoring and appropriate reinforcement of the slope should be adopted to ensure the stability of the slope near road B during mining.

\section{Data Availability}

The data used to support the findings of this study are available from the corresponding author upon request.

\section{Conflicts of Interest}

The authors declare no conflicts of interest regarding the publication of this paper.

\section{Acknowledgments}

Thanks are due to the National Natural Science Foundation of China (51864036, 51574220), the Program for Young Talents of Science and Technology in Universities of Inner Mongolia Autonomous Region (NJYT-19-B33), the Inner Mongolia Natural Science Foundation Project (2018BS05009), the Inner Mongolia Autonomous Region College Scientific Research Project (NJZY18145), and the Innovation Fund Project of Inner Mongolia University of Science and Technology (2017QDL-B11) for supporting this work.

\section{References}

[1] W. B. Zhu, "Study on the instability mechanism of key strata structure in repeating mining of shallow close distance seams," Journal of China Coal Society, vol. 36, no. 6, pp. 1065-1066, 2011.

[2] X. Cui, Y. Gao, and D. Yuan, "Sudden surface collapse disasters caused by shallow partial mining in Datong coalfield, China," Natural Hazards, vol. 74, no. 2, pp. 911-929, 2014.

[3] Z.-S. Tang, H. An, and Z.-P. Shangguan, "The impact of desertification on carbon and nitrogen storage in the desert steppe ecosystem," Ecological Engineering, vol. 84, pp. 92-99, 2015.

[4] M. G. Qian, Key Stata Theory in Strata Control, China University of Mining and Technology Press, Xuzhou, China, 2000.

[5] M. G. Qian and P. W. Shi, Coal Mine Ground Pressure and Control", China University of Mining and Technology Press, Xuzhou, China, 2003.

[6] Q. Huang, "Experimental research of overburden movement and subsurface water seeping in shallow seam mining," Journal of University of Science and Technology Beijing, Mineral, Metallurgy, Material, vol. 14, no. 6, pp. 483-489, 2007.

[7] J. L. Xu, W. B. Zhu, and X. Z. Wang, "Classification of key strata structure of overlying strata in shallow coal seam," Journal of China Coal Society, vol. 34, no. 7, pp. 865-870, 2009.

[8] J. L. Xu, W. B. Zhu, and J. F. Ju, "Supports crushing types in the longwall mining of shallow seams," Journal of China Coal Society, vol. 39, no. 8, pp. 1625-1635, 2014.

[9] D. Zhang, G. Fan, and X. Wang, "Characteristics and stability of slope movement response to underground mining of shallow coal seams away from gullies," International Journal of Mining Science and Technology, vol. 22, no. 1, pp. 47-50, 2012.

[10] D. Zhang, G. Fan, Y. Liu, and L. Ma, "Field trials of aquifer protection in longwall mining of shallow coal seams in China," International Journal of Rock Mechanics and Mining Sciences, vol. 47, no. 6, pp. 908-914, 2010.

[11] L.-q. Ma, D.-s. Zhang, X. Li, G.-w. Fan, and Y.-f. Zhao, "Technology of groundwater reservoir construction in goafs of shallow coalfields," Mining Science and Technology (China), vol. 19, no. 6, pp. 730-735, 2009.

[12] L. Ma, X. Cao, Q. Liu, and T. Zhou, "Simulation study on water-preserved mining in multiexcavation disturbed zone in close-distance seams," Environmental Engineering and Management Journal, vol. 12, no. 9, pp. 1849-1853, 2013.

[13] X. Y. Yu, W. B. Guo, and B. C. Zhao, "FLStudy on mining subsidence law of coal seam with thick overlying loess 
stratum," Coal Science and Technology, vol. 43, no. 7, pp. 6-10, 2015.

[14] H. Z. Zhu, F. L. He, S. B. Zhang, and Z. Q. Yang, "An integrated treatment technology for ground fissures of shallow coal seam mining in the mountainous area of southwestern China: a typical case study," Gospodarka Surowcami Mineralnymi-Mineral Resources Management, vol. 34, no. 1, pp. 119-137, 2018.

[15] Z. Hu, Y. Fu, W. Xiao, Y. Zhao, and T. Wei, "Ecological restoration plan for abandoned underground coal mine site in Eastern China," International Journal of Mining, Reclamation and Environment, vol. 29, no. 4, pp. 316-330, 2015.

[16] C. L. Wang, C. S. Zhang, X. D. Zhao, L. Liao, and S. L. Zhang, "Dynamic structural evolution of overlying strata during shallow coal seam longwall mining," International Journal of Rock Mechanics and Mining Science, vol. 103, pp. 20-32, 2010.

[17] J. C. Wang and Z. H. Wang, "Stability of main roof structure during the first weighting in shallow high-intensity mining face with thin bedrock," Journal of Mining and Safety Engineering, vol. 32, no. 2, pp. 175-181, 2015.

[18] R. Singh, P. K. Mandal, A. K. Singh, R. Kumar, and A. Sinha, "Coal pillar extraction at deep cover: with special reference to Indian coalfields," International Journal of Coal Geology, vol. 86, no. 2-3, pp. 276-288, 2011.

[19] K. Yi, P. L. Gong, and L. Chang, "Overlying strata structures and roof control of working face under thin topsoil and thin bedrock in shallow seam," Journal of China Coal Society, vol. 43, no. 5, pp. 1230-1237, 2018.

[20] A. O. Altun, I. Yilmaz, and M. Yildirim, "A short review on the surficial impacts of underground mining," Scientific Research and Essay, vol. 21, no. 5, pp. 3206-3212, 2010.

[21] J. Li and C. Liu, "Spatio-temporal distribution and gas conductivity of overburden fissures in the mining of shallow thick coal seams," European Journal of Environmental and Civil Engineering, vol. 23, no. 8, pp. 1019-1033, 2019.

[22] W. B. Guo, "Study on the technical characteristics and index of thick coal seam high-intensity mining in coalmine," Journal of China Coal Society, vol. 43, no. 8, pp. 2117-2125, 2018.

[23] G. L. Zhang, J. F. Ju, and J. L. Xu, "Influence of longwall mining on surface runoffs in gully terrain area," Journal of China Coal Society, vol. 41, no. 5, pp. 1219-1226, 2016.

[24] X. P. Lai, P. F. Shan, J. W. Zheng, J. T. Cao, F. Cui, and C. L. Wang, "Physical simulation on strata behavior of large mining height fully mechanized face in shallow-buried and thick seam," Journal of Mining and Safety Engineering, vol. 31, no. 3, pp. 418-423, 2014.

[25] J. Li, C. Liu, and T. Zhao, "Effects of gully terrain on stress field distribution and ground pressure behavior in shallow seam mining," International Journal of Mining Science and Technology, vol. 26, no. 2, pp. 255-260, 2016.

[26] X. F. Wang, D. S. Zhang, and G. W. Fan, "Underground pressure characteristics analysis in back-gully mining of shallow coal seam under a bedrock gully slope," Mining Science and Technology, vol. 21, no. 1, pp. 23-27, 2011.

[27] X. Wang, D. Zhang, C. Sun, and Y. Wang, "Surface subsidence control during bag filling mining of super high-water content material in the Handan mining area," International Journal of Oil, Gas and Coal Technology, vol. 13, no. 1, pp. 87-102, 2016.

[28] Z. Zhang, J. Xu, W. Zhu, and Z. Shan, "Simulation research on the influence of eroded primary key strata on dynamic strata pressure of shallow coal seams in gully terrain," International Journal of Mining Science and Technology, vol. 22, no. 1, pp. 51-55, 2012.
[29] H. Liu, K. Deng, S. Lei, and Z. Bian, "Mechanism of formation of sliding ground fissure in loess hilly areas caused by underground mining," International Journal of Mining Science and Technology, vol. 25, no. 4, pp. 553-558, 2015.

[30] J. Ju and J. Xu, "Surface stepped subsidence related to top-coal caving longwall mining of extremely thick coal seam under shallow cover," International Journal of Rock Mechanics and Mining Sciences, vol. 78, no. 1, pp. 27-35, 2015.

[31] C. Carnec and C. Delacourt, "Three years of mining subsidence monitored by SAR interferometry, near Gardanne, France," Journal of Applied Geophysics, vol. 43, no. 1, pp. 43-54, 2000.

[32] C. Colesanti, S. L. Mouelic, M. Bennani, D. Raucoules, C. Carnec, and A. Ferretti, "Detection of mining related ground instabilities using the Permanent Scatterers technique-a case study in the east of France," International Journal of Remote Sensing, vol. 26, no. 1, pp. 201-207, 2005.

[33] Y. P. Xia, Y. J. Wang, S. Du, X. X. Liu, and H. Y. Zhou, "Integration of D-InSAR and GIS technology for identifying illegal underground mining in Yangquan District, Shanxi Province, China," Environmental Earth Science, vol. 77, no. 8, Article ID 319, 2018.

[34] B. Zhang, C. W. Wang, and H. S. Tan, "Study on stability of district sublevel coal pillar with longwall face re-mining in shallow depth coal seam," Coal Science and Technology, vol. 43, no. 1, pp. 25-27, 2015.

[35] P. Zampoglou and C. Loupasakis, "Mining geohazards susceptibility and risk mapping: the case of the Amyntaio openpit coal mine, West Macedonia, Greece," Environmental Earth Science, vol. 76, no. 15, Article ID 542, 2017.

[36] M. Costea, "Impact of floodplain gravel mining on landforms and processes: a study case in Orlat gravel pit (Romania)," Environmental Earth Science, vol. 77, no. 4, Article ID 119, 2018.

[37] Y. K. Xu, K. Wu, Z. H. Bai, and Z. Q. Hu, “Theoretical analysis of the secondary development of mining-induced surface cracks in the Ordos region," Environmental Earth Science, vol. 76, no. 20, Article ID 703, 2017.

[38] P. Das and R. Mohanty Priya, "Resistivity imaging technique to delineate shallow subsurface cavities associated with old coal working: a numerical study," Environmental Earth Science, vol. 75, no. 8, Article ID 661, 2016.

[39] Itasca consulting group Inc, "FLAC3D user's guide (fast lagrangian analysis of continua in 3dimensions)," 2002.

[40] B.-H. Kim and M. K. Larson, "Development of a fault-rupture environment in 3D: a numerical tool for examining the mechanical impact of a fault on underground excavations," International Journal of Mining Science and Technology, vol. 29, no. 1, pp. 105-111, 2019.

[41] J. Suh and Y. Choi, "Mapping hazardous mining-induced sinkhole subsidence using unmanned aerial vehicle (drone) photogrammetry," Environmental Earth Science, vol. 76, no. 4, Article ID 144, 2017.

[42] H. F. Ma, C. M. Li, and J. Z. Li, "Response characteristics of mining-induced mechanical behavior for coal and rock mass under different advancing speed and its control," Journal of Safety Science and Technology, vol. 12, no. 12, pp. 74-79, 2016.

[43] H. Y. Dai, "Mining subsidence variables and their time-space relationship description," Journal of China Coal Society, vol. 43, no. s2, pp. 450-459, 2018.

[44] C. Zhang, S. Tu, L. Zhang, Q. Bai, Y. Yuan, and F. Wang, "A methodology for determining the evolution law of gob permeability and its distributions in longwall coal mines," Journal 
of Geophysics and Engineering, vol. 13, no. 2, pp. 181-193, 2016.

[45] C. Zhang, S. H. Tu, and Y. X. Zhao, "Compaction characteristics of the caving zone in a longwall goaf: a review," Environmental Earth Sciences, vol. 78, no. 1, Article ID 27, 2019.

[46] J. W. Li and C. Y. Liu, "formation mechanism and reduction technology of mining-induced fissures in shallow thick coal seam mining," Shock and Vibration, vol. 2017, Article ID 1980817, 2017. 